\title{
Executive Compensation in Less Regulated Markets: The Impact of Debt Monitoring
}

\begin{abstract}
This paper shows that in the lightly regulated Alternative Investment Market (AIM) voluntary corporate board structures might not reduce agency costs between shareholder and executive directors. In this less regulated market we find that the extent of debt affects executive pay. Also the theoretical determinants of executive pay affect CEO and other executives' pay and incentives differently in this market. We find no evidence that debt levels affect CEO pay in a matched sample of Main Market firms. Our results suggest that debtholders could be better monitors of executive directors' actions, in comparison to voluntary governance committees in less regulated markets.
\end{abstract}

Keywords: Debt Monitoring, Corporate Governance, Board Structures, Executive Compensation, Executive Incentives, Less Regulated Markets. 


\section{Executive Compensation in Less Regulated Markets: The Impact of Debt Monitoring}

"More generally AIM companies (newly listed) often are simply not aware of some of the interests that minority shareholders might have... Remuneration practices stick out in my mind as an area of concern."

Extract from an interview with an Institutional Investor in Mallin and Ow-Young (2010)

\section{Introduction}

There is an ongoing debate in the literature, media, and policy makers on whether executive compensation practices are efficient and consistent with shareholders interest. Some studies provide evidence that observed executive pay is by and large efficient, but other studies argue that contracting is inefficient and point to executive pay arrangements that are difficult to reconcile within an efficient contracting paradigm. Although this controversial debate has resulted in numerous studies in developed and emerging markets, the literature has largely ignored the pay practices and determinants of CEO and executive directors of companies traded in less regulated markets. In this paper we fill this gap by examining the determinants of executive pay in a lightly regulated market having as primary focus the effect of debt-holders monitoring and additionally considering the impact of voluntary board monitoring structures.

Nielsson (2013) argues that less regulated financial markets can attract similar (high) quality firms as the main regulated markets. He suggests that small and high growth firms are attracted to the lightly regulated markets, not in an attempt to disguise any bad practices/inefficiencies, but because the costs associated with being listed in these markets are smaller. ${ }^{1}$ Doukas and Hoque (2016) also find that even if firms meet the requirements of a heavier regulated market they choose the lighter regulated environment due to lower listing and on-going costs. Both papers concentrated their analysis of less regulated markets on the financial characteristics of the firms listed in these markets. In this paper, we add to this

\footnotetext{
${ }^{1}$ Doidge et al. (2009) and Chhaochharia and Grinstein (2007) show that regulated markets impose significant listing and corporate governance costs.
} 
research by arguing that the extent of regulation in the financial exchanges could impact on agency costs and on monitoring incentives. Specifically, we examine the potential effect of external monitoring by debtholders and of internal monitoring by the board of directors on executive remuneration practices in less regulated markets.

Regulation can influence executive pay directly: for example, in the US, institutions covered by the Troubled Assets Relief Program cannot use options in their long term compensation plans. $^{2}$ However, regulation can also influence pay indirectly: for example regulation can impose stricter corporate governance board structures and these can result in more effective supervision environments, a reduction in agency costs and an impact on pay. Dicks (2012) shows that in competitive labour markets firms with good corporate governance structures can be forced to pay higher levels of pay since firms with weaker or no corporate governance structures in place push pay up for contracting reasons. In such setting regulation on corporate governance can curb pay levels. ${ }^{3}$

In the absence of regulation or in less regulated environments firms could voluntarily replicate some of the structures which regulation could impose. These voluntary corporate governance structures could then serve as monitors of executive directors and of the CEO and could substitute or complement contract alignment and pay incentives. ${ }^{4}$ In this paper we use board structure(s)/board monitoring as a corporate governance mechanism. We do not suggest that voluntary board structures will have a different effect on pay in a less regulated setting but we do propose that it is important to understand if within this setting voluntary board structures have a monitoring role on executive pay. Moreover, we are primarily interested in whether external stakeholders, like debtholders, could have additional firm monitoring

\footnotetext{
${ }^{2}$ In Europe the Capital Requirements Directive (CRD) IV covering prudential rules for banks, building societies and investment firms, states that from 2014 there is a cap on the variable pay to staff.

${ }^{3}$ Yermack (1995) and Cambini et al. (2015) also show that regulation can impact on executive pay.

${ }^{4}$ Alternatively, the light approach to regulation can result in unscrupulous managers being able to capture boards and influence their remuneration packages extracting higher pay levels (Bebchuk and Fried, 2003; Cyert et al., 2002; Hu and Kumar, 2004).
} 
incentives in less regulated markets (due to the lax oversight) and consequently, impose harsher and more effective mechanisms than in a formal regulation structure (as in Siegel, 2005). The consequences of both voluntary and external monitoring could have an impact on executive pay and incentives. Since some of the incentives produced through pay last beyond the date of payment, for example, executives are normally constrained from selling or exercising their options and shares at the grant dates, our analysis also considers the risk (vega) and wealth (delta) incentives held. Also, since financial decisions can be made by all executive board members we do not restrict our analysis to CEO pay and consider the pay and incentives to other executive directors (executive team). To our knowledge, only a few papers (Coles et al., 2006) examine team incentives and to our knowledge, no previous paper has considered executive pay in less regulated markets in developed countries.

We use the Alternative Investment Market (AIM) governed by the London Stock Exchange (LSE) as our example of a less regulated market. We are motivated to consider this market as the AIM is considered a leading stock market for young and high growth companies due to its light regulation (Arcot et al., 2007) and its rules are less onerous than the Main Market in the UK. ${ }^{5}$ There are significant differences between the AIM and the Main Market in the UK which could have implications for executive compensation. Generally, AIM executives are not subject to the same level of scrutiny as those in the Main Market companies. The AIM is not supervised by the Financial Conduct Authority of the UK but by the LSE. ${ }^{6}$ Apart from having to have the

\footnotetext{
${ }^{5}$ A number of studies have examined executive compensation in emerging economies where the governance regulations and law enforcement are weaker than developed countries (see for example Conyon and He, 2011; Gallego and Larrain, 2012; Liang et al., 2015). However, these lightly regulated environments apply to all firms in these emerging markets. We are motivated to examine executive compensation in less regulated markets in developed countries as AIM firms make a choice to list in this less regulated market rather than the Main Market. This is despite in many cases being of similar quality to Main Market firms (Nielsson, 2013) and many meeting the listing requirements of the Main Market (Doukas and Hoque, 2016).

${ }^{6}$ AIM companies are encouraged by the LSE to adhere to the Quoted Companies' Alliance (QCA) guidelines but there is no mandatory requirement to do so (LSE, 2010). The guidelines do state that the board should have at least two independent directors, the company should have separate remuneration
} 
oversight of a group of advisors (nomads), the LSE does not set any special rules for AIM companies and these companies do not have to follow the rules designed for the UK Main Market companies (LSE, 2010), they are therefore subject to much lower levels of compliance, disclosure and transparency. ${ }^{7}$ Doukas and Hoque (2016) describe the key regulatory differences between the Main and the AIM markets including, AIM companies do not have to have a trading record before admission; there is no minimum market capitalisation for these companies and there is no minimum required level of shares in public hands (companies listed in the Main London Stock Exchange Market have to have a minimum market capitalisation of $£ 700,000$ and at least $25 \%$ of its shares have to be in public hands (see Marshall et al., 2013; Nielsson, 2013; Doukas and Hoque, 2016 for further differences between AIM and Main Market firms in the UK). ${ }^{8}$ Moreover, the LSE seems to give clear indication to shareholders that it is expected/acceptable for some AIM companies not to fully apply the combined code. For example in "A Guide to AIM" the LSE states the costs of compliance with the code can in some cases be larger than the benefits.

Our empirical results provide three central findings. Firstly, we show that in the less regulated AIM market, debtholders act as substitutes of contract alignment. Companies with more debt in their capital structure pay smaller remuneration packages to both the CEO and the other executives and both hold less wealth incentives. Since the remuneration packages of

(only with independent directors); audit and nominations' boards and the role of chair and CEO should be separate. Appendix A presents some of the guidelines of the QCA in more detail.

${ }^{7}$ Snell and O'Brien (2008) analysed the 100 largest AIM companies and found that although the large majority comply with some aspects of the combined corporate governance code, only $3 \%$ of those companies fully adopted it. Also, Mallin and Ow-Yong (2010) reported different levels of information disclosure for AIM companies than Main Market firms.

${ }^{8}$ There have been a series of important corporate governance guidelines emerging from UK policy reports which were translated into principles and provisions in the UK Corporate Governance Combined code (Cadbury, 1992; Greenbury, 1995; Hampel, 1998; Higgs, 2003; Walker, 2009). Main Market companies are not obliged to follow the combined code, but they will have to carefully explain to shareholders when they decide not to comply. Shareholders can then discuss their position and through their voting power take action to influence the board. This requirement to "comply or explain" does not apply to AIM companies. 
$\mathrm{CEO}$ and other executives in this market are not as large as in the regulated markets, the economic significance of our results is not strong in overall monetary value, but the results are robust and consistently statistically significant. This finding that more debt results in smaller remuneration packages is in contrast to our matched sample of Main Market firms and the prior empirical evidence on these highly regulated markets which is summarised in Appendix B. ${ }^{9}$ Robustness tests show that it is not the financially distressed firms in our sample or the tenure of the CEO and executives that drive the effect of debt on incentives. Secondly, we find some evidence that board independence can have a substitution effect on contract alignment of executive directors but not of the CEO. Independent boards pay less cash and smaller packages to executive directors and these executives have less of their wealth connected to firm value, but this is not the case for the CEO. Companies with remuneration boards grant more equity awards to both the executives and the CEO but, executives and CEO, do not hold larger wealth incentives. We interpret these results as an indication that (some) voluntary corporate governance board structures/board monitoring in AIM markets may not be acting in shareholders' interests (particularly in the case of the CEO). Debtholders can therefore be better monitors of executive compensation in this market. Finally, we show that the effect of corporate governance board structures is different for executive and CEO pay and incentives and thus the results previously found in the literature for CEO are not necessarily applicable to the other executives. Our results are robust to different specifications of our core variables of interest.

We add to the recent debate on the benefits and problems of less regulated markets. ${ }^{10} \mathrm{We}$ do not find support for more regulation of standard corporate governance board structures like

\footnotetext{
${ }^{9}$ In Appendix B we present a table with some of the central results presented in the previous literature for the UK Main Market. The literature on executive pay and incentives is extensive and thus the table presents the main results relevant for this study.

${ }^{10}$ One of the reasons for the current interest in less regulated markets is the fall in the number of listings in the highly regulated markets (including the LSE Main Market, the US and the Japanese markets), driven mainly by the low new list rate, and the high delist rate. A number of stock exchanges have tried
} 
board independence or the existence of remuneration committee. Moreover, we show that external stakeholders like debtholders can perform a monitoring role even in less regulated markets. Thus, markets, through natural monitoring, can impose alternative controlling mechanisms which can be more effective than formal regulation (Siegel, 2005). ${ }^{11}$

The next section of this paper provides a review of the relevant executive pay literature and sets out our hypotheses. Section 3 presents the data and some descriptive statistics of the sample companies and their remuneration packages to the CEO and the other executive directors. Section 4 describes the research method. Section 5 presents our results and discusses the determinants of the CEO and other executive pay level, and of their risk and performance incentives. Section 6 concludes.

\section{Hypotheses development}

\subsection{The effect of leverage on executive pay and incentives in less regulated markets}

The literature has considered the effect of debt on executive pay (and or incentives) in regulated markets. ${ }^{12}$ Debtholders have an incentive to ensure that managers' actions will not compromise their loan, thus have an incentive to monitor (Jensen, 1986) and the absence of a strict overseeing regulatory authority could enhance this incentive (Krishnaswami et al., 1999).

Less regulated markets are more attractive to smaller, younger, growing firms (Nielsson, 2013; Doukas and Hoque, 2016) and these firms are recognised as being more difficult to

to create markets for smaller firms with less regulation but have failed (for example, Germany's Neuer Markt and France's Nouveau Marché). The success of AIM market in attracting a number of listings by growing and smaller firms is the light regulatory regime (Arcot et al., 2007; Nielsson, 2013).

${ }^{11}$ We thank a referee for this suggestion.

${ }^{12}$ The results found in regulated markets are mixed. Yermack (1995) found that leverage had no effect on option grants, but Lewellen et al. (1987) found a positive relation between leverage and option grants. Fernandes at al. (2013) find a positive relation between leverage and total pay. Ortiz-Molina (2007) suggests a negative effect of leverage on equity like pay. Coles et al. (2006) show that leverage has a negative effect on the CEO wealth incentives (delta) but a positive effect on the CEO risk incentive (vega), albeit weakly significant at a $10 \%$ significance level. 
monitor (Smith and Watts, 1992). Smaller, younger firms have less public debt and rely more on private equity, bank loans, and personal commitments (Berger and Udell, 1998). These private debtholders are expected to provide greater monitoring than public debtholders (Krishnaswami et al., 1999). Also, the ownership structures in less regulated markets can be considerably different, from the highly regulated market, for example the lack of a minimum float requirement can result in more concentrated ownership structures in which single individuals can control the firm (Marshall et al., 2013). Large controlling shareholders can, expropriate firm wealth at the expense of minority shareholders and other stakeholders like debtholders (Shleifer and Vishny, 1997). Thus, debtholders of less regulated markets have incentives to monitor.

We argue that these monitoring incentives can affect executives' pay and incentives. Debtholders' monitoring could reduce the need for manager-shareholder alignment and thus the need for equity like pay and wealth (delta) and risk (vega) incentives. Also, debtholders could perceive stronger links between shareholders and executive directors as indication that the latter can pursue shareholders' interests at the expense of debtholders' interests which could result in larger financial distress costs (John and John, 1993) and to mitigate such costs, in smaller packages and incentives. We thus expect that higher levels of debt result in lower wealth and risk incentives and in lower equity-like pay. Since equity like pay can represent a significant share of total pay, the effect of higher levels of debt can also result in lower pay packages.

However, higher debt increases the risk of equity like components of pay (and incentives) and higher monitoring levels increase executives' risk (Fernandes et al., 2013). Executives of higher debt level firms can thus, demand compensation for these additional risks. This can result in an increase in cash-based pay and, consequently in total pay (but not in larger equity 
pay). The (null) hypothesis below considers our key research question on the impact of debt on executives' pay and incentives in less regulated markets.

Hypothesis 1: Debt levels do not affect CEO pay or incentives in less regulated markets.

Our measure of the extent of debt (leverage) is the book value of debt over total assets (we also define leverage as the ratio of total debt over the book value of equity and we test our results to this alternative specification).

\subsection{The effect of voluntary corporate governance board structures on executive pay and} incentives in less regulated markets

If corporate governance is beneficial, cost effective and value enhancing, companies will want to have good corporate governance in place even if they are not forced to do so by regulation. In less regulated markets, voluntary corporate governance mechanisms like board structures can monitor executives' actions, and thus reduce agency costs and potentially the need for contract alignment. Also, more effective corporate governance structures can increase managers' risk and these managers can be less likely to accept equity like pay. For example, Karlsson et al. (2008) argued that higher CEO turnover rates are associated with the rise of corporate governance. Thus, in less regulated markets effective (voluntary) corporate governance monitoring structures, could substitute the need for contract alignments leading to smaller wealth (delta) and risk incentives (vega) and to less equity like pay (Core et al., 1999) and, potentially, to smaller pay packages. Alternatively, since managers' actions and the outcome of those actions can be difficult to measure, effective monitors can argue for the use of larger equity like components of pay (which can lead to larger pay packages) and thus larger wealth and risk incentives. Monitoring would in this case complement contract alignment.

The increase in pay and incentives can also be the result of weak corporate governance board structures and/or of low protection of shareholder rights. The lenient oversight of less regulated markets can leave room for a less scrupulous CEO and executive directors to exert 
power on their boards and to extract greater or more attractive compensation packages at the expense of shareholders (Bebchuk and Fried, 2004). An important distinction between these last two proposed explanations is that if contract alignment complements monitoring, increases in pay should arise from increases in the equity elements of pay only, and not from increases in the fixed elements of pay. On the contrary, unscrupulous managers could try to extract high compensation also through fixed elements of pay (rent extraction). We consider these possible impacts of board structure as a corporate governance mechanism and managerial rent extraction on executive pay and incentives in (our null) hypothesis 2.

Hypothesis 2: Voluntary corporate governance systems like board structure/board monitoring do not affect executives' pay and incentives in less regulated markets.

Core et al. (1999) suggest that the effectiveness of corporate governance is better assessed considering several characteristics. Therefore, we use a number of variables to consider the monitoring effectiveness of voluntary board structure including the proportion of nonexecutive directors on the board (independence), the existence of a separate remuneration committee and the separation of the CEO and Chair role (some of these voluntary corporate governance measures are covered by QCA guidelines but are voluntary for AIM firms). We also use the size of the board of directors, but we interpret those results with caution since the literature is not clear on what constitutes an effective board size. A number of these corporate governance variables have been studied in regulated and emerging markets with differing theoretical predictions and mixed empirical results.

\subsubsection{Board independence}

An independent board should better defend the interest of shareholders. However, under the managerial power/rent extraction hypothesis independent directors are in the power of executive directors and the CEO (Bebchuk and Fried, 2004). Coakley and Iliopoulou (2006) 
found evidence that boards with larger proportion of independent directors, award smaller compensation packages and have argued that independent directors play an important monitoring role. However, both Fernandes (2008) and Ozkan (2011) found contrary evidence of boards with larger percentages of independent directors' awarding larger compensation packages. We use the percentage of non-executive directors as a proxy for board independence. ${ }^{13}$

\subsubsection{Remuneration committee}

If a remuneration committee acts in the interests of outside shareholders, the existence of a remuneration committee should indicate carefully designed compensation packages (Gordon, 2009). Alternatively, remuneration committees can simply be captured by the executives and the CEO and design pay contracts which have no relation with performance. The remuneration committee can thus just be an instrument of powerful executives and the CEO (Bebchuk and Fried, 2004). Our regressions include a dummy indicator that takes the value of one if the firm has a remuneration committee which is composed only of non-executive directors. For robustness we use also other specifications of this variable. ${ }^{14}$

\subsubsection{Dual role}

\footnotetext{
${ }^{13} \mathrm{We}$ are aware that some non-executive directors may not be independent. According to the UK corporate governance code, companies should indicate in their annual reports if a director is independent. An independent director will not have, or had in the past, significant relations with company, i.e. a shareholder; a shareholder representative; auditor; employee; supplier or significant customer; family member; cross directorships; or call options on the company's shares. This provision, does not apply to AIM companies and thus it is difficult to establish if non-executive directors are indeed independent, also many studies do use the percentage of non-executive directors as a proxy for board independence (Ozkan, 2011).

${ }^{14}$ Other specifications of the remuneration board variable used in robustness tests are a dummy variable which indicates the existence of a remuneration committee (not considering its composition as in Benito and Conyon, 1999), and the percentage of non-executive directors on the remuneration committee (Conyon and Peck, 1998).
} 
Yermack (1996) found indication of larger agency problems in firms in which the CEO and the Chair are the same. The separation of the role of CEO and Chair is considered to be an indicator of independent leadership, leading to stronger boards of directors and effective governance (Jensen, 1993). ${ }^{15}$ We use a dummy variable to indicate a separate role for Chair and CEO as an indication of effective governance, this dummy takes the value of one if the role of chair and CEO is not separated.

\subsection{Are CEO and executives' pay and incentives affected by different factors in less regulated} markets?

The pay and contract alignment of CEO and of the other executive directors can be defined differently. For example, Aggarwal and Samwick (2003) showed that the pay-performance incentive to executives, other than the CEO, was lower but significant. Coles et al. (2006) showed that the risk incentives granted to the CEO are much larger than the risk incentives granted to the other executives. This difference in pay and contract alignment can occur not only because CEO and other executive directors execute different roles but also because they have different levels of influence over firms' strategy and may have different motivation/incentives.

Agency theory, tournament theory and managerial power "theory" all offer explanations why pay can differ at various hierarchical levels (Lambert et al., 1993). ${ }^{16}$ Agency theory argues that contract alignment corrects for the unobservability of managers' effort. Aligning managers' wealth to firm performance, pay induces (unobservable) effort. In this context, managers/directors understand that their effort influences firms' performance and that this performance will impact on their pay. At higher hierarchical levels, it will be more evident

\footnotetext{
${ }^{15}$ There is also the argument that the separation of the roles of CEO and Chair can lead to additional agency costs and that the separation of the role does not really have an impact in company value (Brickley et al., 1997).

${ }^{16}$ We thank a referee for this suggestion.
} 
to managers/directors how their corporate actions can influence firms' performance. Therefore contract alignment should be more widely used and can be more easily justified at CEO level.

Tournament theory also suggests that higher pay and contract alignment could be more needed and more used at higher hierarchical levels (Rosen, 1982). At lower hierarchical levels, managers have an incentive to compete with peers to win the tournament to progress in their career (internally). Thus, according to tournament theory higher pay and incentive alignment should be less important for directors at lower level than the CEO. Finally, managerial power theory suggests that directors could exert their influence on the board and manipulate remuneration decisions in their favour (Bebchuk and Fried, 2004). Since managerial power increases with organisational hierarchy levels (Lambert et al., 1993), the CEO is the organisational role which can most strongly influence its own pay.

All these theories suggest that higher pay and incentive alignment are expected at CEO level. The managerial power theory in particular suggests that, although non-CEO executives can influence the board in an attempt to achieve higher pay and incentives, this behaviour is typically more conspicuous for CEOs. Consequently, if debtholder and/or voluntary corporate board structures exert different effects on the pay and incentives of CEO and of the other executives this can be an indication of CEO power. However, we do not expect to find evidence of less oversight by debtholders and voluntary board structures on the pay and incentives of the CEO in comparison to the pay and incentives of the other executive directors. We consider any potential difference in CEO and other executive pay in (null) hypothesis 3 .

Hypothesis 3: Debtholders and board structure oversight does not affect pay and incentives of CEO and the other executives differently.

\subsection{Other variables affecting executive pay and incentives in less regulated markets}


The literature suggests that pay and incentives can also be influenced by other company characteristics and by the directors' ownership structure. ${ }^{17}$ Guided by this literature, but focusing on the characteristics of AIM firms, we use as control variables in our regressions: size; growth opportunities; companies' risk; past performance and managerial entrenchment/alignment.

The effect of size on CEO pay is well documented (Murphy, 1999). Larger companies need to attract more talented executives and are expected to pay more (Gabaix and Landier, 2008). AIM companies are generally smaller than the firms on the regulated exchanges (Nielsson, 2013). However, there is a substantial difference in the size of the firms in our sample and therefore size is a valid control variable for our sample. ${ }^{18}$ We measure size as the $\log$ of the total assets of our sample firms.

Nielsson (2013) shows that firms with high growth are more likely to list in less regulated markets. Firms with greater growth opportunities can be more challenging to manage as they are considered riskier. Therefore, executives of these firms are expected to be rewarded with larger pay packages. Also, since the management of investment opportunities is difficult to monitor, companies with greater growth opportunities are expected to link more of their executives' wealth to their companies' performance. This should result in larger components of equity like pay and consequently in larger pay packages and incentives (Smith and Watts, 1992). We measure growth opportunities using the market to book ratio.

The company's risk will also increase the risk of the equity like elements of executive pay. This should result in executives demanding larger risk premiums, and consequently larger pay packages (Edmans and Gabaix, 2011). Moreover, riskier companies want to motivate their

\footnotetext{
${ }^{17}$ There is considerable debate in the literature on the types and measurement of variables to be included and the form of the estimating equation (e.g. current or lagged measures).

${ }^{18}$ For example, in 2005 the largest company in our sample (using total assets as the measure of size) was 8168 times larger than the smallest company.
} 
managers to pursue riskier, value enhancing, investments. This could result in larger equity like components of pay and in larger wealth and risk incentives. However, higher risk can indicate higher difficulty in assessing the outcomes from the directors' effort and this could lead to lower equity pay (and incentives) (Aggarwal and Samwick, 1999). Nielsson (2013) shows that AIM firms are not more likely to fail than firms listed in more regulated exchanges, but many AIM firms are at an early stage of their business, they operate in high risk sectors (Arcot et al., 2007) and historically shares on the AIM have been volatile (Financial Times, June 2015). We control for risk as measured by the standard deviation of the previous year daily returns.

Agency theory predicts that executive pay is positively correlated to firm performance. Pay can be used to induce future performance but also to reward past performance (Yermack, 1995), thus better past performance should be positively related to larger executive pay packages and incentives. We use the previous year stock return as a measure of past performance. Agency theory also argues that the misalignment of interests between managers and shareholders can be mitigated by designing compensation contracts that link managers' wealth to company performance (Jensen and Meckling, 1976). It suggests that directors, who are also shareholders, are more likely to take value increasing corporate decisions as they are more likely to be motivated by factors other than remuneration and thus, are less likely to demand large compensation packages. However, there is also the argument that executives with large shareholdings become entrenched, are difficult to monitor and will act against the interests of the other shareholders (Bebchuk et al., 2009). Thus, the net effect of the above arguments will determine the impact of executive director ownership on the size of the executive remuneration packages. Also, firms listed in less regulated markets are more likely to be small (Nielsson, 2013), and in these firms executives can have a higher percentage of firm ownership than Main Market firms. Marshall et al. (2013) show that the executive board 
of a sample of AIM firms listed in 2006 owned on average $13.7 \%$ of the firm's shares. ${ }^{19}$ Therefore, the executive ownership structure of these companies is likely to be an important control variable of pay and incentives. We include the share ownership as a measure of executives' alignment/entrenchment.

In all our regressions we control for time. We also include a dummy which takes the value of one if the CEO changed ${ }^{20}$ and a dummy which takes the value of one if the annual report year end date changed.

\section{Data and descriptive statistics}

\subsection{Data}

Our period of analysis is from 2005 to 2013 . We started our sample with 609 companies listed in the AIM in 2006 based on the alphabetical list of firms. ${ }^{21}$ To be included in the final sample companies had to be alive and their annual report had to be available for at least the first four years, this reduced our sample to 469 companies. Detailed information on pay to all executive directors had to be disclosed in the annual report, which further reduced our sample to 304 companies. ${ }^{22}$ Lastly, share price data and the data related to the explanatory variables had to be available from Datastream. These criteria resulted in a sample of 258 companies and in 9,262 firm/director/year observations. ${ }^{23}$

From the annual report we hand collected data on salary, other benefits, bonus, share awards, option awards and on share and option ownership. We also collected information on

\footnotetext{
${ }^{19}$ Similarly, Arcot et al. (2007) show that on average $20 \%$ of the shares being traded on the AIM are owned by directors, employees, and members of the founding family of the AIM firm.

${ }^{20}$ The CEO change dummy controls for the fact that new CEO might not have been in service for the all year and/or might have been given abnormally high grants to take the role.

${ }^{21}$ In 2006 there were 1634 companies listed in the AIM and thus our initial sample represents $37 \%$ of the whole market.

${ }^{22}$ For robustness in additional tests we adjusted our sample so that only companies alive for at least 5 years were included and so that only companies alive through the 6 years were includes. Our overall results do not change.

${ }^{23}$ A two-sample Kolmogorov-Smirnov test suggests that we cannot reject the null hypothesis that the AIM and our sample are from the same distribution.
} 
the number of options awarded, the number of options held, the exercise price of the options and the time to maturity. Options were then valued using the Black and Scholes (1973) model adjusted for dividends (Merton, 1973). ${ }^{24}$

Using a similar approach to Core and Guay (2002) and Coles et al. (2006) we measure the wealth incentive as the sum of the deltas of the shares and options holdings, times $1 \%$ of the share price, i.e., the pound change in CEO (and other executives) wealth as the share price changes by $1 \%$. The delta of each option is calculated as the partial derivative of Black and Scholes (1973), adjusted for dividends, with respect to share price, the delta of each share is equal to one.

The incentive to increase risk is measured as the sum of the vegas of the CEO and the other executive options, i.e. the pound change in the portfolio of options as volatility changes by $1 \%$, or the partial derivative of Black and Scholes (1973), adjusted for dividends, with respect to volatility (Guay, 1999) and Coles et al., 2006). Guay (1999) shows that the risk incentive provided by shares is much lower than the one provided by share options and of little economic importance, therefore we exclude shares from our measure of risk incentives. ${ }^{25}$ The data on dividend yields, share price, share returns, and risk free rates was collected from Datastream. The volatility used in the Black and Scholes valuation is the annualised standard deviation of the daily share returns of one year up to the annual report year end. The risk free rate is the yield to maturity of the STRIP Gilt with the closest maturity to the maturity of the option being valued. Corporate governance data was also collected from the annual reports, i.e. the number of executive and non-executive directors; the composition of the remuneration committee and the distinction between the Chair and CEO role. The remaining variables are from Datastream and Fame.

\footnotetext{
${ }^{24}$ We follow the standard approach to valuing executive options (Jensen and Murphy 1990; Fernandes et al., 2013).

${ }^{25}$ The same approach appears in Knopf et al. (2002) and Coles et al. (2006).
} 
Although the potential effect of debtholders and corporate governance board structures on CEO pay in highly regulated markets is widely discussed in the literature, for robustness, we include a control sample of listed LSE Main Market firms. These control firms match our sample of AIM firms by industry and by market capitalisation. ${ }^{26}$ As for AIM firms, compensation and corporate governance was hand-collected from annual reports and the matching sample covers CEO and other executives pay and incentives from 2009 until 2012.

\subsection{Descriptive statistics of board and company characteristics in the AIM market}

Table 1 presents some descriptive statistics of our sample and a size comparison between the companies in our sample, the overall companies in the AIM, and UK Main Market in 2010 and in 2013. Compared to the Main Market, the AIM is dominated by small capitalisation companies, in $2010,54 \%$ of the companies listed in the AIM (53\% in 2013) had a market capitalisation smaller than $£ 25$ m (Panel A). In the UK Main Market, in 2010 only $19 \%$ of the companies had a market capitalisation smaller than $£ 25 \mathrm{~m}$, in 2013 that percentage dropped further to $11 \%$. The market capitalisation distribution of the companies in our sample is similar to the distribution of the population of AIM companies (albeit slightly skewed to the left) and therefore we suggest our sample is representative of AIM firms. In 2010, 59\% of the companies in our sample had a market capitalisation smaller than $£ 25 \mathrm{~m}$ an in $2013,55 \%$.

\section{INSERT TABLE 1}

Panel B confirms that the companies in our sample are much smaller (in terms of market capitalisation and total assets) than the companies normally considered in the executive

\footnotetext{
${ }^{26}$ Our control sample includes 176 firms listed in the Main Market. To be included in the sample the firms had to be alive for at least 4 years and compensation and financial information had to be available for this period.
} 
compensation literature. ${ }^{27}$ Also the average market to book ratio is 3.82 , confirming that AIM companies tend to be considered growth companies in comparison to previous research on UK Main Market firms. There is considerable variation in the sample. ${ }^{28}$

Panel $\mathrm{C}$ shows that the size and composition of the boards of directors in AIM firms have not changed considerably between 2005 and 2013. Boards have on average five directors and most of these directors have executive roles (the percentage of non-executive directors' increases slightly from 2005 to 2013). Ozkan (2011) reports larger boards (eight directors) and a larger proportion of non-executive directors (57\%) for the Main Market. The remuneration committee dummy shows that although the majority of companies have remuneration committees composed of solely non-executive directors there are still a significant number of companies that do not. In most companies the role of chair and CEO is held by different people. ${ }^{29}$

\subsection{Descriptive statistics of CEO and other directors' pay and incentives in the AIM market}

Panel A of Table 2 shows some descriptive statistics on the CEO pay and incentives for our sample firms. The total average pay over the nine years was $£ 284,248$. The difference in the pay level of the CEO of large listed companies in the US and in the UK has been addressed in the literature with the UK CEO being consistently reported as much lower. ${ }^{30}$ However, CEO pay in the UK Main Market is large when compared to the values reported in Table 2 for AIM companies. A KPMG (2013) report stated that the median pay to the CEO of the 100 largest

\footnotetext{
${ }^{27}$ As an example, Ozkan (2011) considered pay in UK companies with an average market capitalisation of $£ 1,828 \mathrm{~m}$.

${ }^{28}$ Not tabulated for brevity.

${ }^{29}$ These last two results show that there are a significant percentage of firms which do not adhere to the corporate governance guidelines of the QCA (see Appendix A).

${ }^{30}$ Conyon and Murphy (2000) and Fernandes et al. (2013) show that US CEO receive significantly larger pay packages than UK CEO. Fernandes et al. (2013) argue that the difference in pay can be explained by the risk premium which US CEO receive since their pay packages are more heavily weighted towards performance related pay and thus are riskier than UK CEO pay packages
} 
companies in 2010 was $£ 4.2 \mathrm{~m}$. For the same period, the median total pay for our sample of AIM CEO is $£ 188,424$, which represents $4 \%$ of total pay of CEO of large companies (for the nine years the median is 174,320$).{ }^{31}$

\section{INSERT TABLE 2}

The difference in the pay level of the CEO of large Main Market and AIM companies is considerable, but expected due to differences in firm size between the two markets. Potentially more interesting is the difference in the pay structure. A large proportion of the total CEO pay in AIM companies comes from salary (57\%), followed by options $(23 \%)$; share awards $(8 \%)$ and bonus $(12 \%)$ which are rarely used..$^{32}$ In more detail, in $2010,34 \%$ of total pay in our sample came from option awards; share awards formed only $8 \%$ of total pay. Using a sample of FTSE350 companies Ozkan (2011) shows that in 2005 the proportion of share awards in total pay rose to $28 \%$ (from $14 \%$ in 1999 ) and the proportion of options declined to $5 \%$ (from 24\% in 1999). For a sample of large FTSE100 companies Hass et al. (2014) report that large Main Market companies do not use options as a significant component of CEO pay. They reported that in 2013 share awards constituted $16 \%$ of total pay and share options were only $4 \%$ of total pay. Share option awards also seem to decline for our sample of AIM companies but these companies clearly prioritise the use of options over share awards. In 2013, option awards were $19 \%$ of total pay and share awards were $7 \%$.

Panel B of Table 2 shows some of the descriptive statistics for pay of the other executive directors of AIM firms. Since the number of directors siting in a board of directors varies, for

\footnotetext{
${ }^{31}$ Ozkan (2011) also reports much larger pay packages, the average total pay for larger UK companies in 2005 (reported in 1999 constant terms) is $£ 700,000$. This is three times larger than the average values we found for our sample in 2005 ( $£ 211,914$ - not tabulated).

32 Although the large proportion of total pay comes from salary, companies also use variable/performance related forms of pay. In 2005, salary represented $61 \%$ of total pay and in 2013 $46 \%$, with options contributing $34 \%$ of total pay (as opposed to $28 \%$ in 2005 ). These values are not tabulated.
} 
each company we estimated a "per capita" figure which is the total value of the compensation element paid to the company's executive directors (other than the CEO) divided by the number of executive directors on the board. ${ }^{33}$ Not surprisingly, and as suggested in section 2.4 , for all elements of pay, the CEO is paid more than the other executives. Moreover, the difference in pay is very substantial, for example the average value granted in options to the other executives is only $50 \%$ of the average value granted to the CEO. The t-test of mean differences and the Wilkson rank sum-test of median differences in Table 2 confirm that the differences between CEO and other executives pay are significant for all elements of pay and incentives.

As it was the case for the CEO, option grants are preferred to share award grants, options' awards represent $21 \%$ of total pay and share awards only $7 \%$. The gap between total cash and total pay is larger for the CEO reflecting larger components of equity like pay awards. Over the nine years, salary and bonus was $68 \%(57 \%+11 \%)$ of the total pay package of the CEO and $72 \%(61 \%+11 \%)$ of the total pay package of the other executives. In terms of total pay, the CEO is paid significantly more than other executive directors and the gap widens over time. In 2005 the average total pay of the other executive directors was equivalent to $78 \%$ of the average total pay to the CEO, but in 2013 only $63 \% .^{34}$

The last four rows of Table 2 show some of the descriptive statistics of the wealth and risk incentives for the option and share portfolios of the CEO (panel A) and the other executives (panel B). A change of $1 \%$ in share price value would result in an average change on the CEO portfolio of options of $£ 4,088$, ( $£ 1,960$ for the other executives). Results not tabulated show that in 2008, the delta of the portfolio of options for both the CEO and the other executives was

\footnotetext{
${ }^{33}$ In some cases, the company only discloses the total amount of cash paid to the board, including both executive and non-executive directors in this figure. For these cases our per capita of cash is the total cash paid to the board divided by the total number of board directors. Thus our per capita figures for cash pay and total pay, could understate the amount paid to executive directors

${ }^{34}$ Not tabulated.
} 
at its lowest, but this is expected due to market conditions. ${ }^{35}$ Although these incentives based on share price are small they are, proportionally larger than the results reported in the literature for the larger Main Market companies. Ozkan (2011) reports that in 2005 the portfolio of options of the CEO of 390 UK Main Market companies would change by 0.74 pence per each pound of equity value change, for the same period of time the portfolio of options of AIM CEO would change by 1.16 pence. Over the nine years, per each pound of equity value change, the portfolio of options of the AIM CEO would change by 1.22 pence. Table 2 also shows that, particularly for the $\mathrm{CEO}$, shares provide much larger incentives to alter share price, on average, if the share value changes by $1 \%$ the CEO portfolio of shares will change by $£ 30,095(£ 9,245$ for the other executives). Similarly, to the delta of options, the delta of portfolio of shares is at its lowest for both the CEO and the other executives in 2008.

Ozkan (2011) reports that in 2005 the average ownership of the CEO of large Main Market companies was $2.03 \%$, in the AIM we find that the CEO held $10.84 \%$ of the company shares in the same year (the other executives held $3.52 \%$ ). ${ }^{36}$ Over the nine-year period on average the CEO held $8.5 \%$ of the company shares. Thus, the AIM CEO holds significantly larger proportions of the shares in their companies. ${ }^{37}$ Over the nine years, the CEO had an average total incentive to alter share price by $1 \%$ of $£ 34,183$ ( $£ 11,205$ for the other executives). Not surprisingly, for both the CEO and the other executives, the average incentives to alter share price are considerably larger than the median incentives. This reflects the fact that some of the firms do not have option awards ${ }^{38}$ and that in some firms the CEO holds a large proportion of

\footnotetext{
${ }^{35}$ Results not tabulated show that in 2008 only a small proportion of the options were in the money and the delta of the portfolio of options is small.

${ }^{36}$ Similarly, Marshall et al. (2013) report an average share ownership by AIM CEO and other executives of $13.7 \%$ in 2006 , the average CEO share ownership was $9.9 \%$ (2.96\% for the other executives).

${ }^{37}$ Since the delta of shares is equal to one the Conyon and Murphy measure for shareholdings is simply the CEO share ownership.

${ }^{38}$ In Table 2 options grants and share awards have for every year a median of zero indicating that many companies do not grant options or shares.
} 
the shares available (during our period of analysis in each of the years in at least $46 \%$ of the companies the CEO held $3 \%$ or more of the shares).

In terms of risk incentives, for the CEO, a change of $1 \%$ in volatility over the sample period would result in an average change of $£ 1,741$ in the portfolio of options and for the other executives $£ 852$. Therefore, the incentives held by the other executives are significantly smaller.

\section{Research Method}

We begin our analysis by performing a direct univariate comparison between groups of companies and between the CEO and other executives' roles. We group the companies according to their leverage (above and below the median leverage value); the percentage of non-executive directors on the board (above and below the percentage of non-executive directors); the existence or not of a remuneration board; and lastly the existence or not of a separated chair/CEO role.

In our multivariate analysis we use a generalised method of moments (GMM) model. ${ }^{39}$ The GMM estimation of dynamic panel data model is applied, with a two-step procedure, to examine the impact of the explanatory variables on the different elements of pay ${ }^{40}$ and incentives (dependent variables). The different elements of executive pay, $y_{i t}$, are cash (which includes salary, other benefits and cash bonus); options and share awards; and total pay. The pay incentives are the wealth (delta) and the risk (vega) incentives held by the CEO and the other executive directors. The panel regressions are estimated for each dependent variable using equation (1):

\footnotetext{
${ }^{39}$ Gregg et al. (2012) also considered the dynamics of executive compensation using GMM methods.

${ }^{40}$ The literature has long recognised that the different elements of pay can result in different incentives (Jensen and Murphy, 1990).
} 


$$
y_{i t}=\delta y_{i t-1}+\beta x_{i t}+\mu_{i}+\lambda_{t}+\varepsilon_{i t}
$$

$$
\text { such that: } \quad i=1, \cdots, N ; \quad t=1, \cdots, T
$$

where $y_{i t}$ represents the different measures of pay and incentives for company $i$ in period $t$ and its coefficient $\delta$ captures the effect of lagged pay and incentives on current pay, i.e. the adjustment of pay and incentives. $x_{i t}$ is a vector of our explanatory variables (total assets, leverage, market to book, previous year return, volatility, percentage of CEO ownership, board size, percentage of non-executives, remuneration board and dual); $\beta$ is the vector of coefficients of the explanatory variables; $\mu_{i}$ denotes unobserved time-invariant company-specific effects; $\lambda_{t}$ denotes the year-specific fixed effect (i.e. the time dummies in the regression); and the error term $\varepsilon_{i t}$ is normally distributed with zero mean and variance $\sigma_{i t}{ }^{41}$ In order to take the potential heteroscedasticity and autocorrelation for the error term $\varepsilon_{i t}$ into account, we use robust standard error to make the inference.

The dynamic structure of the model considers that the previous year pay (or incentives), $y_{i t-}$ 1, can influence the current level of pay (or incentives), $y_{i t}$. We should expect this to be the case, since for example remuneration committees often use the previous year pay package of directors as the starting point to set remuneration (Bender, 2003). Also, the fact that elements of pay like salary seldom decrease is probably an indication that companies use previous year(s) pay to set current pay. Moreover, although executives can sell their shares and exercise their options thus affecting their current level of wealth and risk incentives, pay should be

\footnotetext{
${ }^{41}$ We also include a year of end change dummy and a CEO change dummy.
} 
designed to keep (or restore) optimal levels of incentives and thus the previous year incentives should influence the current level of incentives. ${ }^{42}$

To control for unobserved company-specific effects, a first-difference specification of equation (1) is used (Arellano and Bond, 1991; Arellano and Bover, 1995):

$$
\Delta y_{i t}=\delta \Delta y_{i t-1}+\beta \Delta x_{i t}+\Delta \varepsilon_{i t}
$$

A problem with using lagged first-differenced dependent variables as regressors is that, the conventional estimators are biased and inconsistent. However, the estimators based on a GMM framework are consistent if $N \rightarrow \infty$ and T remains fixed (Arellano and Bond, 1991). Arellano and Bond (1991) first proposed GMM-DIF estimation approach to conduct dynamic panel analysis. The GMM-DIF estimator is based on taking first difference in order to wipe out unobserved effects. This approach prevents us from estimating time-invariant effects, such as the change of CEO, 'CEO change'. Arellano and Bover (1995) and Blundel and Bond (1998) proposed the 'system GMM estimator', GMM-SYS which combines GMM-DIF estimator with additional moment conditions for the equations in levels. In this paper we apply GMM-SYS to conduct the estimation for equation (2). Moreover, the regressors $\Delta x_{i t}$ and $\Delta y_{i t-1}$ are not strictly exogenous which causes an endogeneity problem for the specification in equation (2). In other words, shocks on executive pay (and incentives) which remain in the error term may affect changes in the companies' characteristic composition. To control for endogeneity, the $t$ 2 and $t-3$ lagged levels of the explanatory variables are used as instruments. ${ }^{43}$ The instruments

\footnotetext{
${ }^{42}$ Boschen and Smith (1995), Main et al. (1996), Conyon and Murphy (2000) and Boschen et al. (2003) all suggest the importance of modelling the dynamics of executive compensation. Models which only consider the contemporaneous response of compensation to firm performance implicitly assume that the long run relation between compensation and performance is the same as contemporaneous relation. In other words a pay increase resulting from an unexpected good performance remains in the level of pay indefinitely (Boschen and Smith, 1995).

${ }^{43}$ The lagged levels are valid instruments since they are uncorrelated with the error term $\Delta \varepsilon_{i t}$ of the model in first-differences.
} 
selection is a crucial step, since the GMM estimators will only be valid if the selected instruments are correlated with the endogenous regressors but not correlated with the error term. This is tested with a standard Sargan test. For the estimated model, significant secondorder serial correlation of the first-differenced error term, $\Delta \varepsilon_{i t}$, indicates serial correlation in the original level error term, $\varepsilon_{i t}$. This is checked with the Arellano and Bond (1991)'s first, $A R(1)$, and second order, $A R(2)$, autocorrelation test statistics are presented in the results tables. ${ }^{44}$

Table 3 presents the correlation matrix for our independent and control variables and shows no significant problems with multicollinearity. Therefore, all our independent variables are included in the analysis.

\section{INSERT TABLE 3}

\section{Results}

\subsection{Determinants of CEO and executive directors' pay and incentives in the AIM market}

Table 4 shows some preliminary results of tests of differences of means of executive pay and incentives for the CEO (panel A) and the other executive directors (Panel B). The CEO and the other executives of companies with remuneration boards are paid significantly more; they also receive more cash and equity like instruments and hold larger risk incentives. The CEO and other executive directors of firms with more independent boards of directors receive more cash and larger compensation packages. The CEO of these companies hold less wealth incentives.

\section{INSERT TABLE 4}

Table 4 also shows that AIM companies in which the CEO is also chair, pay significantly smaller compensation packages and less cash and equity like instruments to the other executives, and less cash CEO, but not smaller compensation packages. In companies in which

\footnotetext{
${ }^{44}$ Although, we believe that it is important to consider the dynamics of pay and thus the GMM methodology should be applied, for robustness and comparability we also run our regressions using a fixed effect regression model since this is the most widely used research method in prior executive pay studies.
} 
there is a dual role of chair and CEO, the CEO has significantly larger wealth and lower risk incentives, but the other executives have lower wealth and risk incentives.

Finally, companies with more debt, pay significantly smaller compensation packages to executives other than the CEO. The CEO and the other executives of companies with more leverage hold significantly less wealth and risk incentives and are paid smaller equity like awards. These initial results seem to offer some support to the hypothesis that debtholders and corporate governance board structures affect (some) pay and incentives (hypotheses 1 and 2) and that this effect can be different for CEO and the other executives (hypothesis 3 ). The different effect of debtholders and corporate governance board structures on pay and incentives of CEO and other executives could potentially also be confirmed by the results of the t-test of mean differences between CEO and other executives pay and incentives presented in Panel B. For the four group categories of variables considered: remuneration board; dual; board independence and leverage; CEO and other executives are awarded significantly different pay and incentives.

These initial results offer some support towards our hypothesis but it is important to interpret these univariate results with caution. For example, larger companies are more likely to have a separate remuneration board, thus the remuneration board can be acting as a proxy for company size in which case our result is simply telling us that larger companies pay executives more.

Table 5 and 6 show the results on the main research questions on the determinants of executive pay for the CEO (Panel A) and for the other executive directors (Panel B) ${ }^{45}$ Model 1 in the Table 5 and 6 presents the results for our sample of AIM firms and Model 2 the results for a matching sample of Main Market firms. The control sample was defined using firm size

\footnotetext{
${ }^{45}$ The Sargan test does not indicate correlation between the instruments and the error term. Also, the serial correlation tests, $A R(1)$ and $A R(2)$ that the instruments are valid.
} 
(market capitalisation) and industry as the matching criteria. We present the results using the GMM methodology and, for robustness, the results for a fixed effects panel data regression but our discussion will concentrate on the GMM results. ${ }^{46}$

\subsection{The effect of leverage on executive pay and incentives in the AIM market}

To test hypothesis 1, we analyse the effect of leverage on pay (Table 5) and incentives (Table 6). Panels A and B of Table 5 (Model 1), show that companies with more debt in their capital structure pay less cash to their CEO and grant less equity awards to the other executives (significant at the 5\% level). Moreover, these highly leveraged companies pay significantly smaller compensation packages to both CEO and other executives (significant at the $5 \%$ and $1 \%$ levels respectively). The results for fixed effects confirm the effect of debt on reducing other executives overall compensation (significant at the $1 \%$ level for other executives). Panel A shows that a $1 \%$ increase in leverage would reduce the CEO pay by $0.12 \%$ and the other executive pay by $0.09 \%$. We acknowledge this is small in monetary terms. As an example, considering the average value of CEO pay in Table 2, the reduction in total pay would be $£ 341$. But in this market compensation packages are relatively smaller than other markets and thus it is important to consider the effect in relative terms.

These results are in contrast with our matching sample of Main Market companies. Model 2 suggests that debt does not affect pay of CEO and other executives in the more regulated LSE Main Market. This is in line with Voulgaris et al. (2010) which suggest that debt does not affect pay of CEO and other executives in the more regulated LSE Main Market. Our finding that debt affects CEO pay for lightly regulated firms is nevertheless in contrast to Fernandes et al. (2013) who found the opposite result for CEO of Main Market companies (see Appendix B).

\footnotetext{
${ }^{46}$ For brevity we do not present the fixed effects panel data regression for the matching sample of Main market firms. The results are available on request from the authors.
} 
Table 6 reports the results from the regressions of the determinants of wealth and risk incentives for the CEO (panel A) and the other executives (panel B). Highly leveraged firms' structure their pay so that, the CEO and the other executives have less of their wealth linked to share price and so that they have fewer incentives to increase company's risk (significant at the $5 \%$ level or lower). Coles et al. (2006) report the opposite result for Main Market firms. They found a positive relation between vega and leverage (albeit only significant at a $10 \%$ confidence level) and argued that riskier companies (with more debt) will want to provide their managers with more risk incentives. Our results for the matching sample of Main market firms (Model 2) suggest that leverage does not affect the wealth and risk incentives of CEO and other executives. The results for fixed effects confirm the effect of debt on the CEO wealth incentive and on the risk incentives to the other executives (significant for the wealth incentive in the case of the CEO and the risk incentive for the other executives). In terms of economic significance, an increase of $1 \%$ in leverage results in a decrease of $0.16 \%$ on CEO wealth incentives (risk incentives $0.21 \%$ ) and $0.146 \%$ on the other executives' wealth incentives (risk incentives $0.153 \%$ ). Using the average CEO incentive values in Table 2, this implies that if leverage increases by $1 \%$ the CEO’s wealth incentive decreases by $£ 55$. We again acknowledge that this value is of low economic significance but the volatility levels of AIM firms are high, in our sample for example the average volatility of share returns is around $56 \%$. Since the wealth incentive measure presents the change in CEO wealth per $1 \%$ change of share value and since, with such large values of volatility, the change may be of several orders of magnitudes larger, our reported wealth incentives can be a conservative estimate. ${ }^{47}$

Therefore, our results show that in the less regulated AIM market, debt affects pay and incentives and thus, we reject hypothesis 1 . The results support the argument that either

\footnotetext{
${ }^{47}$ In other words, if the wealth incentive is significantly larger, than our estimate in Table 2, then the monetary change resulting from a change of $1 \%$ in leverage will also become much larger.
} 
debtholders act as monitors or, firms try to mitigate shareholder/bondholder agency costs by reducing shareholder-managers' contract alignment (Jensen, 1986; John and John, 1993). Thus, a substitution effect of debtholders monitoring over contract alignment exists in the less regulated AIM market and is in contrast to our matched sample and prior evidence on Main Market firms. $^{48}$

\section{INSERT TABLES 5 \& 6 HERE}

\subsection{The effect of voluntary corporate governance board structures on pay and incentives of} CEO and other executives in the AIM market

To test hypothesis 2 , we analyse the effect of board size, a remuneration committee, Chair/CEO dual role and board independence on pay and incentives. Table 5 shows that board independence ( $\%$ of non-executives) does not seem to affect cash or the total amount of compensation paid to the CEO (Panel A Model 1). There is some evidence that more independent boards grant more equity like awards, an increase of $1 \%$ in board independence leads to an increase of $2.26 \%$ in option and/or share awards. Although, this result could suggest that independent boards complement monitoring with contract alignment, the results in Table 6 (Panel A) do not support this interpretation. Table 6 (Panel A) shows that board independence does not affect CEO risk or wealth incentives. The fixed effects results are broadly the same. We thus conclude that board independence does not complement, or substitute CEO pay and incentives in the less regulated AIM market.

The results for the matching sample of Main Market firms (Table 5 Model 2 Panel A) also indicate that board independence does not affect CEO pay and these are consistent with some of the results reported in the literature for Main Market firms e.g. Conyon and Peck (1998) and Gregory-Smith (2012). However, the results are inconsistent with Ozkan (2007) and Gregg et

\footnotetext{
${ }^{48}$ For robustness we repeated all our tests using an alternatives definition of leverage (debt over book equity). Our results do not change.
} 
al. (2012) who show a positive relation between board independence and pay in Main Market firms (see Appendix B).

Interestingly, board independence affects pay and wealth incentives of the other executive directors (Tables 5 and 6 Panel B Model 1 and 2). As the percentage of non-executive directors' of AIM firms increases the executive directors (other than the CEO) receive less cash and smaller compensation packages and they also hold less wealth incentives (broadly confirmed by fixed effects results). This seems to support that non-executives monitor executive directors' other than the CEO and that this monitoring role has a substitution effect, but no such result is found for the CEO. Fiegener et al. (2000) and Bebchuk and Fried (2005) have suggested that CEO power plays a substantial role shaping pay arrangements. The difference in our results for the CEO and the other executives can be an indication of CEO power in the less regulated AIM.

The results for the matching sample of Main Market firms (Table 6 Model 2 Panel B) indicate that board independence of those firms seem to affect the cash and total package paid to executives other than the CEO. Executives of companies with more independent boards receive more cash and larger pay packages but do not hold larger wealth or risk incentives. Gregg et al. (2012) found the same result for a sample of large UK companies.

We also find that larger boards pay significantly larger amounts of cash and option and/or share awards and overall packages to executive directors other than the CEO and that they hold larger incentives to alter share price (Tables 5 and 6 Panel B Model 1). This result could suggest that larger boards where the percentage of non-executive directors does not increase are less effective at monitoring the other executive directors (Ozkan, 2011). CEO pay and incentives of AIM firms are not affected by board size. Pay and incentives of CEO and other executives of our matched Main Market sample companies (Model 2) are also largely unaffected by board 
size. ${ }^{49}$ This in line with the results found in the literature on CEO pay on the heavily regulated markets (Ozkan, 2007)..$^{50}$

Table 5 shows companies in which the CEO is also the chair (dual) grant significantly less equity awards to both the CEO and the other executives and pay smaller compensation packages to the other executives (but not to the CEO). Moreover, CEO and executives in these firms hold less risk incentives and the other executives also hold less wealth incentives (Table 6). These results could indicate that these companies are more subject to agency costs since the CEO actions will not have the oversight of an independent chair and the other executives do not have strong wealth incentives to pursue shareholders' interests. Nevertheless, our results should be interpreted with caution since in our sample only $19 \%$ of the firm/year observations correspond to cases in which the role of CEO and chair are held by the same individual. The results for Model 2 show that the dual role CEO/Chair does not affect cash or total pay of CEO and other executives in UK Main Market companies. This result is consistent with the literature (Appendix B). Executives, other than the CEO, of Main Market firms in which the CEO and chair role are with the same individual, hold less risk incentives, but as suggested above the results on the Dual variable should be interpreted with caution.

Not surprisingly, Table 6 shows that when the CEO owns a larger share of the company, the CEO has significantly larger incentives to alter share price the CEO also has larger incentives to increase risk. However, Table 5 (Panel A) shows that this CEO is not paid more. ${ }^{51}$ This can indicate that the interests of the CEO and shareholders are well aligned and there is no evidence of CEO entrenchment leading to larger pay. In Table 5 Model 2, we also find no

\footnotetext{
${ }^{49}$ The effect of board size on the risk incentive held by other executives is an exception. Executives other than the CEO of companies with larger boards have larger risk incentives.

${ }^{50}$ The results on board size are difficult to interpret though since it is not clear from the literature if large or smaller boards represent better governance.

${ }^{51}$ These results are consistent with the fixed effects methodology.
} 
evidence of entrenchment for the Main Market firms, the CEO that holds a larger share of the company is paid smaller compensation packages.

Benito and Conyon (1999) and Gregory-Smith (2012) argue that the remuneration committee does not affect pay in Main Market firms, but Main and Johnston (1993) and Voulgaris et al. (2010) show that remuneration committees increase the CEO total pay although not equity like pay. ${ }^{52}$ Our results show that less regulated AIM companies that have a remuneration committee pay larger equity awards to both the CEO and the other executive directors (Table 5 Panel A and B). Also, executive directors of companies with remuneration boards receive more cash and larger compensation packages (Table 5 Panel B) and hold larger risk incentives but, do not hold larger wealth incentives (Table 6 Panel B). An increase in cash and total pay could indicate that the remuneration committee is compensating executives for risk exposure. Executives (other than the CEO) do hold larger risk incentives in companies with remuneration committees, but they do not hold larger wealth incentives (Table 6 Panel B). Moreover, those remuneration committees do not impact CEO wealth or risk incentives. The results offer some support to the view that remuneration committees are not designing pay packages which better align the interests of shareholders and directors. For robustness, we repeated our tests to the different definitions of remuneration board described in section 2.2, and our overall results remain. ${ }^{53}$ The results for the fixed effects in Tables 5 and 6 are generally in the same direction as the GMM results.

Overall the results seem to provide some (weak) evidence to reject hypothesis 2 for the CEO. Board size does not affect CEO pay but board independence, remuneration committees and the $\mathrm{CEO} / \mathrm{Chair}$ role affect the equity element of pay. Importantly, with the exception of the

\footnotetext{
${ }^{52}$ Due to data constraints we cannot test in model 2 the effect of remuneration committee on CEO pay. We nevertheless discuss the results previously found in the literature for the Main Market.

${ }^{53} \mathrm{We}$ do not have data on the remuneration committees of the companies in our matched Main Market sample.
} 
$\mathrm{CEO} /$ chair role, corporate governance structures do not affect $\mathrm{CEO}$ held incentives. However, the results do provide strong evidence to reject hypothesis 2 for the other executive directors. Board size and remuneration boards affect all elements of pay to the other executives; board independence and CEO/Chair role affect some of the elements of pay. Importantly, all of these corporate governance board characteristics affect the incentives held by the other executives although; only board independence seems to perform a clear (monitoring) role which can result in an increase in company value. ${ }^{54}$

The difference in the results for the CEO and the other executives, particularly in relation to the effect of corporate governance board structures on pay and incentives supports the rejection of hypothesis 3. Independent boards, though monitoring, substitute contract alignment for the other executive directors but this is not found for the CEO. As suggested above, this may indicate that CEO may exert some power over the board, but this cannot be done by the other executives and thus offer some support to the managerial power hypothesis.

Regarding our control variables on the influence of other factors on executive pay and incentives, Tables 5 and 6 show that in the case of the CEO, pay and incentives persist (Table 5 Panel A Model 1) which offers support to our GMM specification. Interestingly, equity grants will decrease if the CEO received larger grants in the previous year. This can indicate that companies do try to guarantee that some of the CEOs' wealth is linked to company value but only up to a certain level. As expected larger firms pay higher compensation packages and greater amounts of cash and options and share awards to both the CEO and the other executive directors and they also hold larger wealth and risk incentives. This result is consistent for both GMM and fixed effects, Main and AIM companies, and both the CEO and the other executives. Companies with greater growth opportunities reward both the CEO and the other executives with larger amounts of equity and pay packages, and also pay more cash to executives other

\footnotetext{
${ }^{54}$ We interpret the results on board size and $\mathrm{CEO} /$ Chair with caution due to number of observations.
} 
than the CEO. The CEO, but not the other executives, of the Main Market growth opportunity companies are also paid more cash and receive a larger overall pay (Table5 Model 2). In AIM companies both the CEO and the other executives of these companies have larger wealth and risk incentives. In contrast, in the Main Market the CEO and the other executives of high growth firms hold less risk incentives, but surprisingly do not hold larger wealth incentives.

Executives, other than the CEO, of companies that performed well are granted larger equity like awards and hold larger incentives to alter share price, they also receive less cash. This can indicate that companies reward good performance with share and option awards. But, no such result was found for the CEO. Riskier AIM companies, grant more share and/or option awards to both the executives and the CEO (Table 5) but the opposite result is found for the CEO Main Market companies (Table 5 - Model 2). The CEO and the other executives of riskier AIM companies hold larger risk incentives and are granted larger equity awards. In contrast, The CEO of Main market riskier firms is paid smaller equity awards and compensation packages.

5.4. Robustness test - is the effect of debt on executive pay driven by managers' fear of bankruptcy?

Milidonis and Stathopoulos (2014) find a non-monotonic relation between CEO risk incentives and firm risk. They argue that because of career concerns the CEO of highly leveraged firms and firms with high probability of default can have an incentive to reduce risk. Since more debt can lead to higher probability of default risk, managers of high leveraged distressed firms could try to reduce risk through reducing their pay and their wealth and risk incentives. ${ }^{55}$ Thus, in highly leveraged and distressed firms managerial risk aversion effects, due to career concerns, could dominate wealth effects (Milidonis and Stathopoulos, 2014).

\footnotetext{
${ }^{55}$ Managers could want to reduce firm's risk even if this results in lower pay packages. Similarly, Berk et al. (2010) suggest that employees will accept temporary pay cuts if this helps avoid bankruptcy.
} 
We interpret the negative effect of leverage on pay and wealth and risk incentives as an indication of debtholders monitoring, or of actions to mitigate shareholder and bondholder conflict. However, it could be argued that CEO and the other executives risk aversion could explain our results. If our result on the effect of leverage on executive pay is driven only by the high leverage and financially distressed firms in our sample then, the effect of leverage on pay and incentives should be stronger in these firms. Conversely in financially healthy firms, leverage should not have a negative effect on the pay and incentives of the CEO and of the other executives. To test this hypothesis, we run our GMM regressions controlling for financial distress with a dummy variable and an interaction term. The dummy variable takes the value of one if the firm is classified as financially distressed. Firms are classified as in financial distress if their Altman's Z score is below 1.8. ${ }^{56}$ The interaction term is the product of leverage and the distress dummy variable. We add the distress dummy variable and the effect of leverage on pay and wealth incentives (measured by $\beta_{1}$ Leverage $+\beta_{2}$ (Leverage $x$ Distress dummy)) to our regression model in Model 3. If it is only in the financially distressed firms that leverage negatively affects pay and incentives, our interaction term should be significantly negative and the isolated effect of leverage on pay and incentives (measured by $\beta_{1}$ ) should not be significant.

The results for the effect of leverage and financial distress on CEO and other executives pay are in Tables 7 (Model 3) and the effect on wealth and risk incentives in Table 8 (Model 3). Model 3 in Table 7 (Panels A and B) shows that, financially distressed companies do pay significantly less to the CEO but not to the other executives. As before, leverage impacts negatively total pay of the CEO but the same result is not found for the other executives. Table 8 (Model 3) shows that the CEO and the other executives of financially distress companies hold significantly less wealth incentives. But, importantly, as before, leverage affects

\footnotetext{
${ }^{56}$ The data for Altman $\mathrm{Z}$ score is from Fame database. Since we were not able to find the Altman score for some of our sample companies in these tests our sample is reduced to 1824 firm/year observations.
} 
negatively the CEO and the other executives' wealth incentive. Also, consistent with our earlier results executives other than the CEO of more leveraged companies hold larger risk incentives. In all specifications the interaction term is not significant thus the effect of leverage on pay in financially distress firms is not dominating the results. These results generally show that financially distressed firms in our sample are not driving the effect of leverage on pay and incentives.

\section{INSERT TABLES $7 \& 8$ HERE}

\subsection{Ownership structure and other monitoring effects}

One important omission from our empirical analysis so far is ownership structure. ${ }^{57} \mathrm{We}$ argue in this paper that in less regulated markets debtholders and (voluntary) corporate governance board structures have the incentive to monitor the CEO and the other executives and that this can affect the need for contract alignment and thus impact pay and incentives. Due to their economic incentives, (outside) shareholders also have an incentive to monitor and this incentive should be larger in companies with concentrated ownership (Dyl, 1988; Hambrick and Frinkelstein, 1995). Closer monitoring should reduce the need for contract alignment (Hart, 1995) and should prevent rent-extraction, resulting in lower pay. Alternatively, active and engaged larger shareholders will want to hire the best directors and these directors can demand higher pay. However, the best quality directors should demand larger equity like pay but not larger cash pay since they will believe in their ability to influence company value which should result in a larger value of their equity and consequently pay.

A number of authors have shown a negative relation between share ownership and executive pay (Dyl, 1988; Core et al., 1999; Cyert et al., 2002; Ozkan, 2007; Gregory-Smith, 2012). However, Stapledon (1996) and Voulgaris et al. (2010) fail to demonstrate a relation

\footnotetext{
${ }^{57}$ We do include CEO share of ownership in our analysis, but we omit outsiders' ownership. Clearly, companies in which the CEO does not own any company shares can still have concentrated ownership.
} 
between institutional shareholders and pay levels and Conyon and Leech (1994) and Cosh and Hughes (1997) show little relation between outside ownership and pay. These papers have not considered less regulated markets.

Using data from the Fame database we identified owners that hold 3\% or more of the company shares and we added their holdings in the company (Blockholder Ownership) ${ }^{58} \mathrm{We}$ then repeated our regression analysis including the Blockholder Ownership variable in the model. Since the CEO can also be a blockholder we exclude the variable Percentage of CEO ownership from this analysis. Model 4 in Tables 7 and 8 present the results. Table 7 (Model 4) shows that the effect of leverage on CEO pay is no longer present if we include the blockholder ownership variable, but Table 8 (Model 4 Panel A) shows that leverage still has a significant negative effect on the CEO wealth and risk incentives. The effect of leverage on the other executives pay is consistent with the previous results, but effect of leverage on the wealth and risk incentives is no longer present (Panel B Model 4). As our sample is reduced in this test and the results are still broadly in line with our central results in Table 5 and 6 we suggest that this provides evidence that leverage reduces the other executives pay and incentives.

The results in Tables 7 and 8 for the corporate governance board structure variables are also mainly consistent with our previous results. Remuneration boards pay larger amounts of cash and larger packages to the CEO but do not grant larger equity awards. ${ }^{59}$ As before the other executives of companies with remuneration boards receive more cash and total pay but now they do not receive more equity awards. Also consistent with our earlier results, remuneration boards do not impact on the $\mathrm{CEO}$ and the other executive wealth incentive. Also, now more independent boards do not influence CEO pay and, as before, do not influence CEO incentives but they do influence the other executives pay and incentives. Board size has no

\footnotetext{
${ }^{58}$ This information is not available for all companies in our sample, and this reduced the number of company/years to 1759 .

${ }^{59} \mathrm{CEO}$ option and share awards are still significant at a $10 \%$ significance level.
} 
effect on CEO incentives or pay, but it does influence the other executives' pay and wealth incentives. Finally, companies in which outside blockholders own larger shares of the company do not pay differently from other firms to the CEO or the other executives and these results are consistent with Conyon and Leech (1994), Stapledon (1996), and Voulgaris et al. (2010).

5.6. Robustness test - are the effects of debt and voluntary corporate governance structure on executive pay and incentives driven by managers' experience?

Our analysis so far ignores the potential confounding effect of managers' characteristics and ability on corporate financial and remuneration decisions. For example, more experienced managers are likely to understand the implications of debt finance and be paid more, more risk averse managers may influence the firm to adopt lower leverage and may prefer to have less of their wealth linked to firm value (resulting in lower deltas). May (1995) suggests that managers ability and style does impact on a firms' financial policy and shows that leverage decreases with CEO tenure. Graham et al. (2013) also show that more optimistic CEOs prefer higher leverage levels and Bertrand and Schoar (2003) show that managers' characteristics are related to both a firms' financial policies and managers' compensation.

The same confounding effect may be occurring between managers' characteristics or their ability and corporate governance and remuneration policies. If managers can influence board structure they could use this influence to enhance their pay. Hermalin and Weisbach (2003) model a process in which a CEO ability influences board selection and suggest that better managers influence board structure. Similarly, Bertrand and Schoar (2003) show that managers characteristics are related to a firms' corporate governance of the firm.

If managers' characteristics affect leverage and corporate governance decisions and if these same characteristics can impact on how much and how managers are paid, then by not including firm characteristics this could influence our results. To test for this, we run the same 
analysis as before but including dummy variables which measure CEO and the other executives' tenure. ${ }^{60}$ Tenure is used in this context as a proxy for managerial specific skills and experience (May, 1995). ${ }^{61}$ The measure of tenure is a dummy variable which identifies CEO and other executive directors which tenure is in the lower quartile of the tenure distribution and one dummy variable which identifies the CEO and other executive director which is in the upper quartile of the tenure distribution.

Our results appear on Table 7 and Table 8 under Model 5. The CEO with more experience (longer tenure) is not paid more and holds less risk incentives. The CEO with less experience holds less wealth incentives, which may simply indicate that being in the firm for less time this CEO has less accumulated option or share awards. Experience seems to more strongly affect pay and incentives of the other executive directors. Executives with lower experience are paid significantly less cash and option and share awards and hold less wealth and risk incentives. Higher levels of experience also result in less equity like awards and less wealth and risk incentives, but these executives are paid larger compensation packages.

Importantly, our previous results on the effect of leverage and board structure on pay and incentives generally persist. As before, debtholders seem to be performing a monitoring effect and influence pay and incentives of both the CEO and the other executives, the only difference in the results is that now options awarded to the other executives are not influenced by the oversight of debtholders. The key results for the effect of voluntary corporate board structures on pay and incentives also persist. Exceptions, for the other executives, are that cash pay is no longer affected by the size of the board or the percentage of non-executives, and the latter now seems to affect risk incentives. Firms with remuneration boards do not pay

\footnotetext{
${ }^{60}$ Tenure is the number of years in company and these data is from the annual reports.

${ }^{61} \mathrm{We}$ acknowledge that tenure can also be a proxy for managerial entrenchment but to the extent that we control for managerial share ownership we do not see this as a major concern.
} 
significantly larger equity awards. Also, as before, the results show that voluntary board structures affect CEO and other executives pay and incentive differently.

\section{Conclusion}

This paper considers CEO and other executives' pay and incentives in the less regulated AIM in the UK. Although the importance of this market is recognised by its regulator (the LSE) one of its features and attraction to firms is the fact that it is "lightly" regulated and AIM companies do not have to follow the same corporate governance requirements as Main Market companies. Thus, AIM companies and their executives are not subject to the same level of scrutiny as the Main Market companies.

Our key result shows that in this less regulated market, debt affects both the pay packages and the incentives held by executives. This result is in contrast to a matched sample of Main Market firms and prior empirical evidence on highly regulated markets. Some corporate governance board structure variables, do have an impact on the pay and incentives of the executive directors and on the pay of the CEO, but this impact, can be different for the CEO and the other executives. Executive directors, other than the CEO, of companies with more independent boards have less of their wealth linked to company value and are paid less, which seems to indicate that the board performs a monitoring role. However, no such result was found for the CEO. Companies with remuneration committees pay larger compensation packages and more cash to executive directors and pay larger equity awards to both the executive directors and the CEO. Importantly, we do not find an effect of remuneration committees on the level of wealth incentives held by the CEO and the executives and thus, find no evidence that remuneration contracts designed by these committees do result in better alignment incentives.

Some could argue that stronger regulation of corporate governance board structures resulting in for example more independent boards, and/or in more expert or diverse boards 
could result in better pay incentives (Department for Business Innovation and Skills, 2011). Our results do not offer support to this view since we do not show that firms, which voluntarily adopt recommended board structure practices ${ }^{62}$ set compensation practices which better align the interests of directors and shareholders (this is particularly true for the CEO). But importantly, these results have to be interpreted with caution since the effect of board characteristics on CEO and board pay can be subject to endogeneity problems (see Hermalin and Weisbach, 2003).

Overall our results suggest that debtholders in the AIM market seem to be performing an important monitoring role on executive pay and/or firms design executive pay to mitigate shareholder/debtholder agency costs and this result is not driven by firms with a higher probability of default risk or by the CEO and other executives' tenure. In this less regulated market, debtholders could be better monitors than voluntary corporate governance board structures.

\footnotetext{
${ }^{62}$ In our sample $50 \%$ of the companies' board is comprised of non-executive directors and around $70 \%$ of the companies have a full independent remuneration committee.
} 


\section{References}

Aggarwal, R. and Samwick, A. 1999. The other side of the trade-off: The impact of risk on executive compensation. Journal of Political Economy. 107: 65-105.

Aggarwal, R. and Samwick, A. 2003. Performance incentives within firms: The effect of managerial responsibility. The Journal of Finance. 58:1613-1650.

Arcot, S. R., Black, J. and Owen, G. 2007. From local to global: The rise of AIM as a stock market for growing companies. London School of Economics, available at: www.londonstockexchange.com/NR/rdonlyres/4B0DF62A-BE1E-44F5-8616-

EA2891873F1D/0/AIMshortreport.pdf.

Arellano, M. and Bond, S. 1991. Some tests of specification for panel data: Monte Carlo evidence and an application to employment equations. The Review of Economic Studies. 58: 277-297.

Arellano, M. and Bover, O. 1995. Another look at the instrumental variable estimation of error components models. Journal of Econometrics. 68: 29-51.

Bebchuk, L. A. and Fried, J. M. 2003. Executive compensation as an agency problem. Journal of Economic Perspectives. 17: 71-92.

Bebchuk, L. A. and Fried, J. M. 2004. Pay without performance the unfulfilled promise of executive compensation. UC Berkeley Public Law Research Paper No. 537783.

Bebchuk, L. A. and Fried, J. M. 2005. Pay without performance: Overview of the issues. Journal of Corporation Law. 30: 647-668.

Bebchuk, L.A., Cohen, A. and Ferrell, A. 2009. What matters in corporate governance? Review of Financial Studies. 22: 783-827.

Bender, R. 2003. How executive directors' remuneration is determined in two FTSE 350 utilities. Corporate Governance: An International Review. 11: 206-217.

Benito, A and Conyon, M. 1999. The governance of directors' pay from UK companies. Journal of Management and Governance. 3: 117-136.

Berger, A. N. and Udell, G. F. 1998. The economics of small business finance: The roles of private equity and debt markets in the financial growth cycle. Available at SSRN: http://ssrn.com/abstract=137991.

Berk, J. B., Stanton, R. and Zechner, J. 2010. Human capital, bankruptcy, and capital structure. Journal of Finance. 65: 891-926.

Bertrand, M. and Schoar, A. 2003. Managing with style: the effect of managers on firm policies. The Quarterly Journal of Economics. 118: 1169-1208.

Black, F. and Scholes, M. 1973. The pricing of options and corporate liabilities. The Journal of Political Economy. 81: 637-654.

Blundel, R.W. and Bond, S. R. 1998. Initial conditions and moment restrictions in dynamic panel data models. Journal of Econometrics. 87: 115-143.

Boschen, J. F. and Smith, K. J. 1995. You can pay me now and you can pay me latter. The dynamic response of executive compensation to firm performance. Journal of Business. 68: 577-608.

Boschen, J. F., Duru, A., Gordon, L. A. and. Smith, K. J. 2003. Accounting and stock price performance in dynamic CEO compensation arrangements. The Accounting Review. 78: 143-168.

Brickley, J. A., Coles, J. L. and Jarrell, G. 1997. Leadership structure: separating the CEO and chairman of the board. Journal of Corporate Finance. 3: 189-220.

Cadbury Report. 1992. Report of the Committee on the Financial Aspects of Corporate Governance. London: Gee.

Cambini, C., Rondi, L. and De Masi, S. 2015. Incentive compensation in energy firms: Does regulation matter? Corporate Governance: An International Review. 23: 378-395.

Chhaochharia, V. and Grinstein, Y. 2007. Corporate governance and firm value: The impact of the 2002 governance rules. Journal of Finance. 62: 1789-1825.

Coakley, J. and Iliopoulou, S. 2006. Bidder CEO and other executive compensation in UK M\&As. European Financial Management. 12: 609-631.

Coles, J. L., Naveel, D. D. and Naveel, L. 2006. Managerial incentives and risk taking. Journal of Financial Economics. 79: 431-468.

Conyon, M. 1997. Corporate governance and executive education. International Journal of Industrial Organization. 15: 493-509. 
Conyon, M. J. and He, L. 2011. Executive compensation and corporate governance in China. Journal of Corporate Finance. 17(4): 1158-1175.

Conyon, M. and Leech, D. 1994. Company performance and corporate governance. Oxford Bulletin of Economics and Statistics. 56: 229-247.

Conyon, M. and Murphy, K. J. 2000. The prince and the pauper? CEO pay in the United States and United Kingdom. Economic Journal. 110: 640-671.

Conyon, M. and Peck, S. 1998. Board control, remuneration committees, and top management compensation. The Academy of Management Journal. 41: 146-157.

Core, J. and Guay, W. 2002. Estimating the value of employee stock option portfolios and their sensitivities to price and volatility. Journal of Accounting Research. 40: 613-630.

Core, J., Holthansen, R. and Larcker, D. 1999. Corporate governance, chief executive officer compensation, and firm performance. Journal of Financial Economics. 43: 195-218.

Cosh, A. and Hughes, A. 1997. Executive remuneration, executive dismissal and institutional shareholdings. Workshop on Managerial Compensation, Strategy and Firm Performance, Elsevier Science.

Cyert, R., Kang, S.-K. and Kumar, P. 2002. Corporate governance, takeovers, and top-management compensation: Theory and evidence. Management Science. 48: 453-469.

Dicks, D. L. 2012. Executive compensation and the role for corporate governance regulation. The Review of Financial Studies. 25: 1971-2004.

Department for Business Innovation and Skills (BIS). 2011. Executive remuneration discussion paper. $1-46$.

Doidge, C., Karolyi, G.A., Lins, K., Miller, D. P. and Stulz, R. M. 2009. Private benefits of control, ownership, and cross-listing decisions. The Journal of Finance. 64: 425-466.

Doukas, J.A. and Hoque, H. 2016. Why firms favour the AIM when they can list on Main market? Journal of International Money and Finance. 60: 378-404.

Dyl, E. 1988. Corporate control and management compensation: Evidence on the agency problem. Managerial and Decision Economics. 9: 21-25.

Edmans, A. and Gabaix, X. 2011. The effect of risk on the CEO market. Review of Financial Studies. 24: 2822-2863.

Fernandes, N. 2008. Board compensation and firm performance: The role of "independent" board members. Journal of Multinational Financial Management. 18: 30-44.

Fernandes, N., Ferreira, M., Matos, P. and Murphy, K. J. 2013. Are U.S. CEOs paid more? New international evidence. The Review of Financial Studies. 26: 323-367.

Fiegener, M. K., Brown, B. M., Druex, D. R. V. and Dennis, W. J. J. 2000. CEO stakes and board composition in small private firms. Entrepreneurship Theory and Practice. 24: 5-24.

Gabaix, X. and Landier, A. 2008. Why has CEO pay increased so much? Quarterly Journal of Economics. 121: 49-100.

Gallego, F. and Larrain, B. 2012. CEO compensation and large shareholders: Evidence from emerging markets. Journal of Comparative Economics. 40: 621-642.

Gordon, J. 2009. Say on pay: Cautionary notes on the UK experience and the case for shareholder optin. Working Paper No. 343 from The Center for Law and Economic Studies Columbia University School of Law.

Graham, J.R., Harvey, C.R., Puri, M. 2013. Managerial attitudes and corporate actions. Journal of Financial Economics. 109: 103-121.

Greenbury, R. 1995. Directors' remuneration. Financial Services Authority.

Gregg, P., Jewell, S. and Tonks, I. 2012. Executive pay and performance: Did bankers' bonuses cause the crisis? International Review of Finance. 12: 89-122.

Gregory-Smith, I. 2012. Chief executive pay and remuneration committee independence. Oxford Bulletin of Economics and Statistics. 74: 510-531.

Guay, W. 1999. The sensitivity of CEO wealth to equity risk: an analysis of the magnitude and determinants. Journal of Financial Economics. 53: 43-71.

Hambrick, D. and Frinkelstein, S. 1995. The effects of ownership structure on conditions at the top: The case of CEO pay raises. Strategic Management Journal. 16: 175-193.

Hampel. 1998. Committee on Corporate Governance: Final report. London: Gee Publishing Ltd. Hart, O. 1995. Corporate governance: Some theory and implications. Economic Journal. 105: 678-698. 
Hass, L., Liu, J., Young, S. and Zhang, Z. 2014. Measuring and rewarding performance: theory and evidence in relation to executive compensation. CFA Society Report.

Hermalin, B. and Weisbach, M. 2003. Boards of directors as an endogenously determined institution: A survey of the economic literature. FRBNY Economic Policy Review. 9: 7-22.

Higgs, D. 2003. Review of the role and effectiveness of non-executive directors. London: Financial Reporting Council.

Hu, A. and Kumar, P. 2004. Managerial entrenchment and payout policy. Journal of Financial and Quantitative Analysis. 39: 759-790.

Jensen M. C. 1986. Agency cost of free cash flow, corporate finance and takeovers. The American Economic Review. 76: 323-329.

Jensen, M. C. 1993. The modern industrial revolution, exit, and the failure of internal control systems. Journal of Finance. 48: 831-880.

Jensen M. C. and Meckling, W. H. 1976. Theory of the firm: Managerial behavior, agency costs and ownership structure. Journal of Financial Economics. 3: 305-360

Jensen, M. C. and Murphy, K. 1990. Performance pay and top-management. Journal of Political Economy. 98: 225-264.

John, T. A. and John, K. 1993. Top-management compensation and capital structure. Journal of Finance. 48: 949-974.

Karlsson, P. O., Neilson, G. L. and Webster, J. C. 2008. CEO succession 2007: The performance paradox. Strategy Business. 51: 76-89.

Knopf, J., Nam, J. and Thornton, J. 2002. The volatility and price sensitivities of managerial stock option portfolios and corporate hedging. Journal of Finance. 57: 801-814.

KPMG. 2013. Guide to Directors' Remuneration: http//www.kpmg.co,/uk/en.

Krishnaswami, S., Paul, A., Spindt, S. P. and Subramaniam, V. 1999. Information asymmetry, monitoring, and the placement structure of corporate debt. Journal of Financial Economics. 51: 407435 .

Lambert, R. A., Larcker, D. F., Weigelt, K. 1993. The structure of organisational incentives. Administrative Science Quarterly. 38: 438-461.

Liang, H., Renneboog, L. and Sun, S. L. 2015. The political determinants of executive compensation: Evidence from an emerging economy. Emerging Markets Review. 25: 69-91

Lewellen, W. G., Loderer, C. and Martin, K. 1987. Executive compensation and executive incentive problems: an empirical analysis. Journal of Accounting and Economics. 9: 287-310.

London Stock Exchange (LSE), 2010. A Guide to AIM. Published by: White Page Ltd, 17 Bolton Street, London W1J 8BH, United Kingdom.

Main, B. G., Bruce, A. and Buck, T. 1996. Total board remuneration and company performance. Economic Journal. 106: 1627-1644.

Main, B. G. M., and Johnston, J. 1993. Remuneration committees and corporate governance. Accounting and Business Research. 23: 351-362.

Mallin, C. and Ow-Yong, K. 2010. The UK alternative investment market - Ethical dimensions. Journal of Business Ethics. 95: 223-239.

Marshall, A., Kemmitt, M. and Pinto, H. 2013. The determinants of foreign exchange hedging in Alternative Investment Market firms. The European Journal of Finance. 19: 89-111.

May, D. 1995. Do managerial motives influence firm risk reduction strategies? The Journal of Finance. 50: 1291-1308.

Merton, R. C. 1973. Theory of rational option pricing. The Bell Journal of Economics and Management Science. 4: 141-183.

Milidonis, A. and Stathopoulos, K. 2014. Managerial incentives, risk aversion and debt. Journal of Financial and Quantitative Analysis. 49: 453-481.

Murphy, K. J. 1999. Executive Compensation, in Handbook of Labor Economics. Orley Ashenfelter and David Card, eds. Amsterdam: North Holland. 2485-2563.

Nielsson, U. 2013. Do less regulated markets attract lower quality firms? Evidence from the London AIM market. Journal of Financial Intermediation. 22: 335-352.

Ortiz-Molina, H. 2007. Executive compensation and capital structure: The effects of convertible debt and straight debt. Journal of Accounting and Economics. 43: 69-93. 
Ozkan, N. 2007. Do corporate governance mechanisms influence CEO compensation? An empirical investigation of UK companies. Journal of Multinational Financial Management. 17: 349-364.

Ozkan, N. 2011. CEO compensation and firm performance: An empirical investigation of UK panel data. European Financial Management. 17: 260-285.

Rosen, S. 1982. Authority, control and the distribution of earnings. Bell Journal of Economics. 13: 311323.

Shleifer, A. and Vishny, R. 1997. A survey of corporate governance. The Journal of Finance. 52: 737783.

Siegel, J. 2005. Can foreign firms bond themselves effectively by renting U.S. securities laws? Journal of Financial Economics. 75: 319-359.

Smith, C. W. and Watts, L. R. 1992. The investment opportunity set and corporate financing, dividend, and compensation policies. Journal of Financial Economics. 32: 263-292.

Snell, D. and O'Brien, S. 2008. Corporate governance and AIM. An assessment of the governance procedures adopted by AIM companies. Price Waterhouse Cooper.

Stapledon, G. 1996. Regulation of corporate governance: will it improve corporate performance? Australian Accounting Review. 12: 11-15

Voulgaris, G. Stathopoulos, K. and Walker, M. 2010. Compensation consultants and CEO pay: UK evidence. Corporate Governance: An International Review. 18: 511-526.

Walker, D. 2009. A review of corporate governance in UK banks and other financial industry entities, Financial Services Authority.

Yermack, D. 1995. Do corporations award stock options effectively? Journal of Financial Economics. 39: 237-269.

Yermack, D. 1996. Higher market valuation of companies with a small board of directors. Journal of Financial Economics. 40: 185-221. 
Table 1 - Descriptive Statistics of AIM Sample Firms and Main Market Firms

All monetary values are referred to the end of December 2010 and the Table comprises information on 258 companies listed on the UK AIM market. Market Capitalisation is the market value of the companies' equity in $£ 000$ (Datastream). Sales are the total sales in $£ 000$ (Datastream). Leverage is the ratio of book value of debt to total assets (Datastream). Total Assets is the book value of the assets in $£ 000$ (Datastream). Book value of equity is shareholders' funds in $£ 000$. Market to Book is the ratio of the market value of equity to the book value of equity. Boardsize is the number executive and nonexecutive directors siting on the board (Annual report). Percentage (\%) of non-executives is the ratio of the number of non-executives to board size (Annual report). Following the QCA guidelines the remuneration dummy takes the value of 1 if the company has a remuneration committee composed solely of non-executive directors (Annual report). Dual is a dummy variable that takes the value of 1 if the role of chairman and Chief Executive is held by the same individual (Annual report).

Panel A - Size distribution of companies in the sample, the full AIM and the Main Market.

\begin{tabular}{|c|c|c|c|c|c|c|}
\cline { 2 - 7 } \multicolumn{1}{c|}{} & \multicolumn{3}{|c|}{2010} & \multicolumn{3}{|c|}{2013} \\
\hline $\begin{array}{c}\text { Market } \\
\text { Capitalisation } \\
\text { (fmillion) }\end{array}$ & $\begin{array}{c}\text { Our } \\
\text { sample }\end{array}$ & AIM & $\begin{array}{c}\text { Main } \\
\text { Market }\end{array}$ & $\begin{array}{c}\text { Our } \\
\text { sample }\end{array}$ & AIM & $\begin{array}{c}\text { Main } \\
\text { Market }\end{array}$ \\
\hline $0-2$ & $11.17 \%$ & $8.00 \%$ & $2.59 \%$ & $10.6 \%$ & $7.54 \%$ & $1.08 \%$ \\
\hline $2-5$ & $15.53 \%$ & $12.30 \%$ & $2.29 \%$ & $15.3 \%$ & $11.41 \%$ & $2.49 \%$ \\
\hline $5-10$ & $12.62 \%$ & $13.50 \%$ & $5.08 \%$ & $9.4 \%$ & $12.88 \%$ & $2.71 \%$ \\
\hline $10-25$ & $19.90 \%$ & $20.60 \%$ & $9.16 \%$ & $20.0 \%$ & $21.07 \%$ & $4.76 \%$ \\
\hline $25-50$ & $16.02 \%$ & $17.90 \%$ & $9.06 \%$ & $15.9 \%$ & $15.09 \%$ & $6.60 \%$ \\
\hline $50-100$ & $10.19 \%$ & $11.50 \%$ & $10.56 \%$ & $11.8 \%$ & $12.51 \%$ & $9.63 \%$ \\
\hline $100-250$ & $8.25 \%$ & $9.00 \%$ & $17.23 \%$ & $10.0 \%$ & $11.13 \%$ & $16.02 \%$ \\
\hline $250-500$ & $4.37 \%$ & $4.00 \%$ & $11.40 \%$ & $3.5 \%$ & $3.77 \%$ & $12.66 \%$ \\
\hline More than 500 & $1.94 \%$ & $2.20 \%$ & $29.40 \%$ & $3.5 \%$ & $1.84 \%$ & $38.31 \%$ \\
\hline
\end{tabular}

Panel B - Descriptive statistics of sample characteristics.

\begin{tabular}{|l|c|c|c|c|}
\hline & Average & Median & Max & Min \\
\hline Market capitalisation & 54,881 & 16,663 & $2,085,794$ & 0.00 \\
\hline Leverage & 14 & 5 & 289 & 0.00 \\
\hline Total assets & 56,857 & 19,641 & $3,006,118$ & 9.33 \\
\hline Market to book & 3.82 & 1.51 & 358.11 & 0.01 \\
\hline
\end{tabular}

Panel C - Descriptive statistics of board characteristics (annual)

\begin{tabular}{|c|c|c|c|c|c|c|c|c|c|c|c|}
\hline & & 2005 & 2006 & 2007 & 2008 & 2009 & 2010 & 2011 & 2012 & 2013 & Overall \\
\hline \multirow{2}{*}{ Board size } & Mean & 5.42 & 5.48 & 5.56 & 5.53 & 5.33 & 5.39 & 5.45 & 5.30 & 5.39 & 5.43 \\
\hline & Median & 5 & 5 & 5 & 5 & 5 & 5 & 5 & 5 & 5 & 5 \\
\hline \multirow{2}{*}{$\%$ of non-executives } & Mean & 45 & 46 & 46 & 48 & 48 & 49 & 51 & 50 & 50 & 48.11 \\
\hline & Median & 50 & 50 & 50 & 50 & 50 & 50 & 50 & 50 & 50 & 50 \\
\hline \multirow{2}{*}{ Remuneration dummy } & Mean & 0.63 & 0.63 & 0.65 & 0.69 & 0.69 & 0.68 & 0.65 & 0.67 & 0.70 & 0.67 \\
\hline & Median & 1.00 & 1.00 & 1.00 & 1.00 & 1.00 & 1.00 & 1.00 & 1.00 & 1.00 & 1.00 \\
\hline \multirow{2}{*}{ Dual } & Mean & 0.21 & 0.15 & 0.18 & 0.17 & 0.23 & 0.22 & 0.19 & 0.20 & 0.22 & 0.20 \\
\hline & Mean & 0.00 & 0.00 & 0.00 & 0.00 & 0.00 & 0.00 & 0.00 & 0.00 & 0.00 & 0.00 \\
\hline
\end{tabular}




\section{Table 2 - Descriptive Statistics of Executive Pay in the AIM Market}

The table presents the annual average (mean) and median, of the different elements of pay and incentives to CEO (panel A) and the other executive directors (panel B). Monetary pound values are adjusted for inflation and refer to 31/12/2010 and to a sample of 258 AIM listed companies. Options Grants are the pound value of the total number of options granted in a specific year, valued at year end using the Black and Scholes model adjusted for dividend payment (Annual report and Datastream). Share awards are the pound value of the total number of shares granted in a specific year, valued at year end and assuming that the maximum number of shares under grant will vest (Annual report and Datastream). Salary is the pound value of the annual salary and other benefits (Annual report). Bonus is the pound value of the annual bonus (Annual report). Total pay is the pound value of total pay obtained summing all components of pay. Wealth incentive options is the sum of the deltas of the options holdings, times $1 \%$ of the share price. The delta of each option is calculated as the partial derivative of Black and Scholes (1973), adjusted for dividends, with respect to share price. Wealth incentive shares is number of shares held (plus the number of shares under award) times $1 \%$ of the share price at year end. Wealth incentive is the sum of the deltas of the options and of the shares holdings, times $1 \%$ of the share price. Vega is the risk incentive and is the pound change in the portfolio of options as volatility changes by $1 \%$, or, the partial derivative of Black and Scholes (1973), adjusted for dividends, with respect to volatility. The estimated t-test values of mean differences and the Wilkson rank-sum test of median differences are in parentheses, * and ** indicates that the null hypotheses of no difference between the two samples (CEO and other executives) is rejected at the $5 \%$ and $1 \%$ level respectively.

\begin{tabular}{|c|c|c|c|c|c|c|}
\hline & \multicolumn{3}{|c|}{$\begin{array}{c}\text { Panel A - Descriptive statistics of CEO pay and } \\
\text { incentives }\end{array}$} & \multicolumn{3}{|c|}{$\begin{array}{c}\text { Panel B - Descriptive statistics of other executives pay and } \\
\text { incentives }\end{array}$} \\
\hline & Mean & $\begin{array}{l}\text { Percentage over total } \\
\text { pay }\end{array}$ & Median & Mean & $\begin{array}{l}\text { Percentage over total } \\
\text { pay }\end{array}$ & Median \\
\hline Option awards & 67,291 & $23 \%$ & 0 & $\begin{array}{c}33,975 \\
(3.22 * *)\end{array}$ & $21 \%$ & $\begin{array}{c}0 \\
(6.61 * *)\end{array}$ \\
\hline Share awards & 22,476 & $8 \%$ & 0 & $\begin{array}{c}10,800 \\
(3.32 * *)\end{array}$ & $7 \%$ & $\begin{array}{c}0 \\
\left(8.14^{* *}\right)\end{array}$ \\
\hline Salary & 162,020 & $57 \%$ & 144,426 & $\begin{array}{c}97,832 \\
(18.77 * *)\end{array}$ & $61 \%$ & $\begin{array}{c}82,491 \\
(28.38 * *)\end{array}$ \\
\hline Bonus & 32,460 & $11 \%$ & 0 & $\begin{array}{c}17,506 \\
(4.96 * *)\end{array}$ & $11 \%$ & $\begin{array}{c}0 \\
\left(14.66^{* *}\right)\end{array}$ \\
\hline Total pay & 284,248 & - & 174,320 & $\begin{array}{l}160,114 \\
\left(9.50^{* *}\right)\end{array}$ & - & $\begin{array}{r}105,827 \\
(27.38 * *)\end{array}$ \\
\hline Wealth options & 4,088 & - & 358 & $\begin{array}{c}1,960 \\
(6.79 * *)\end{array}$ & - & $\begin{array}{c}317 \\
\left(16.41^{* *}\right)\end{array}$ \\
\hline Wealth shares & 30,095 & - & 2,319 & $\begin{array}{c}9,245 \\
(8.08 * *) \\
\end{array}$ & - & $\begin{array}{c}703 \\
\left(19.78^{* *}\right) \\
\end{array}$ \\
\hline Wealth incentive & 34,183 & - & 3,610 & $\begin{array}{l}11,205 \\
(8.73 * *)\end{array}$ & - & $\begin{array}{c}737 \\
\left(26.4^{* *}\right)\end{array}$ \\
\hline Risk incentive & 1,741 & - & 243 & $\begin{array}{c}852 \\
(8.47 * *)\end{array}$ & - & $\begin{array}{c}200 \\
\left(16.94^{* *}\right)\end{array}$ \\
\hline
\end{tabular}




\section{Table 3 - Correlation Matrix of Explanatory Variables of Executive Pay}

The table refers to 258 AIM listed companies. Leverage is the ratio of book value of debt to total assets (Datastream). Total Assets is the book value of the assets in $£ 000$ (Datastream). Market to Book is the ratio of the market value of equity to the book value of equity (Datastream). Previous year return is the previous year percentage change in the company share value, adjusted for dividends and capital changes (Datastream). Volatility is the annualised standard deviation of the daily share returns of one year up to the annual report year end (Datastream). Percentage of CEO Ownership is the CEO share ownership and it is calculated as the number of shares held by the CEO over the total number of shares outstanding (Annual report). Boardsize is the number of executive and non-executive directors siting on the board (Annual report). Percentage of non-executives is the ratio of the number of non-executives to board size (Annual report). Correlation coefficients are tested under the null of Pearson correlation coefficients being zero. Correlation coefficients with a $*$ are significant at the $5 \%$ level. ** are significant at $1 \%$ level.

\begin{tabular}{|l|c|c|c|c|c|c|c|}
\hline & Assets & Leverage & $\begin{array}{c}\text { Market } \\
\text { to Book }\end{array}$ & $\begin{array}{c}\text { Previous } \\
\text { year } \\
\text { return }\end{array}$ & Volatility & $\begin{array}{c}\text { Percentage of } \\
\text { CEO } \\
\text { ownership }\end{array}$ & Board size \\
\hline Total Assets & 1.00 & & & & & & \\
\hline Leverage & -0.00 & 1.00 & & & & & \\
\hline Market to Book & -0.02 & 0.02 & 1.00 & & & & \\
\hline Previous year return & 0.04 & 0.00 & 0.02 & 1.00 & & & \\
\hline Volatility & $-0.05^{*}$ & $0.07^{* *}$ & -0.00 & $-0.22^{* *}$ & 1.00 & & \\
\hline Percentage of CEO ownership & -0.01 & -0.00 & -0.00 & -0.00 & -0.01 & 1.00 & \\
\hline Board size & $0.30^{* *}$ & 0.04 & -0.03 & $0.06^{* *}$ & $-0.15^{* *}$ & -0.02 & 1.00 \\
\hline Percentage of non-executives & $0.10^{* *}$ & 0.02 & 0.01 & $-0.04^{*}$ & 0.06 & $-0.07^{* *}$ & $0.15^{* *}$ \\
\hline
\end{tabular}


Table 4 - Differences of Compensation and Incentives of Executive Pay

The table refers to 258 AIM listed companies and show the results of t-tests of differences of means of compensation and incentives of executive pay. Panel A shows the results for the CEO data and panel B for the other executive data. Monetary pound values are adjusted for inflation, refer to 31/12/2010 and to a sample of 258 AIM listed companies and are the mean values of the respective group. Cash is the sum of salary, other benefits and bonus. Wealth incentive options is the sum of the deltas of the options holdings, times $1 \%$ of the share price. The delta of each option is calculated as the partial derivative of Black and Scholes (1973), adjusted for dividends, with respect to share price. Wealth incentive shares is number of shares held (plus the number of shares under award) times $1 \%$ of the share price at year end. Vega is the risk incentive and is the pound change in the portfolio of options as volatility changes by $1 \%$, or, the partial derivative of Black and Scholes (1973), adjusted for dividends, with respect to volatility. Leverage is the ratio of book value of debt to total assets (Datastream). Percentage of non-executives is the ratio of the number of non-executives to board size (Annual report). Remuneration Board is a dummy variable which takes the value of 1 if the company has a remuneration committee composed of only nonexecutives (Annual report). Dual is a dummy variable that takes the value of 1 if the CEO and the chair is the same individual (Annual report). The estimated test values are in parentheses. The $t$ tests of difference of means between CEO and other executives are presented in separate columns in Panel B under "T test of difference of means CEO and other", * and ** indicates that the null hypotheses of no difference between the two samples is rejected at the $5 \%$ and $1 \%$ level respectively.

\begin{tabular}{|c|c|c|c|c|c|c|}
\hline & & Cash & Options and Share Awards & Total Pay & Wealth Incentive & Risk Incentive \\
\hline Remuneration board & $\begin{array}{l}\text { Yes } \\
\text { No }\end{array}$ & $\begin{array}{c}220,012 \\
144,334 \\
\left(-8.88^{* *}\right)\end{array}$ & $\begin{array}{c}113,034 \\
43,937 \\
\left(-4.15^{* *}\right)\end{array}$ & $\begin{array}{c}333,046 \\
188,272 \\
(-7.22 * *)\end{array}$ & $\begin{array}{c}32,479 \\
37,603 \\
(0.84)\end{array}$ & $\begin{array}{c}2,032 \\
1,174 \\
\left(-4.96^{* *}\right)\end{array}$ \\
\hline Dual & $\begin{array}{l}\text { Yes } \\
\text { No }\end{array}$ & $\begin{array}{l}170,462 \\
200,399 \\
(2.32 * *)\end{array}$ & $\begin{array}{c}75,179 \\
93,344 \\
(0.47)\end{array}$ & $\begin{array}{c}245,642 \\
293,743 \\
(1.08)\end{array}$ & $\begin{array}{c}55,375 \\
29,092 \\
(-2.71 * *)\end{array}$ & $\begin{array}{c}1,066 \\
1,905 \\
\left(3.39^{* *}\right)\end{array}$ \\
\hline Percentage of non-executives & $\begin{array}{l}\text { Below median } \\
\text { Above median }\end{array}$ & $\begin{array}{c}183,156 \\
205969 \\
(-2.64 * *)\end{array}$ & $\begin{array}{c}67,354 \\
112,203 \\
(-2.24 *)\end{array}$ & $\begin{array}{c}250,510 \\
318,172 \\
\left(-2.86^{* *}\right)\end{array}$ & $\begin{array}{l}39,482 \\
28,936 \\
\left(2.18^{*}\right)\end{array}$ & $\begin{array}{c}1,314 \\
2.170 \\
(-4.54)\end{array}$ \\
\hline Leverage & $\begin{array}{l}\text { Below median } \\
\text { Above median }\end{array}$ & $\begin{array}{c}197,731 \\
193,203 \\
(0.48)\end{array}$ & $\begin{array}{c}107,355 \\
73,097 \\
(1.70 *) \\
\end{array}$ & $\begin{array}{c}304,724 \\
266,300 \\
(1.61)\end{array}$ & $\begin{array}{l}38,906 \\
29,792 \\
(1.88 *)\end{array}$ & $\begin{array}{c}2,161 \\
1,340 \\
(4.33 * *)\end{array}$ \\
\hline
\end{tabular}

Panel B - Differences in mean of other executives pay level and incentives

\begin{tabular}{|c|c|c|c|c|c|c|c|c|c|c|c|}
\hline & 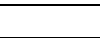 & \multicolumn{2}{|c|}{ Cash } & \multicolumn{2}{|c|}{ Option and share awards } & \multicolumn{2}{|c|}{ Total Pay } & \multicolumn{2}{|c|}{ Wealth incentive } & \multicolumn{2}{|c|}{ Risk Incentive } \\
\hline & & Mean & $\begin{array}{c}\text { T test of } \\
\text { difference of } \\
\text { means CEO } \\
\text { and other }\end{array}$ & Mean & $\begin{array}{c}\text { T test of } \\
\text { difference of } \\
\text { means CEO } \\
\text { and other }\end{array}$ & Mean & $\begin{array}{c}\text { T test of } \\
\text { difference of } \\
\text { means CEO } \\
\text { and other }\end{array}$ & Mean & $\begin{array}{c}\text { T test of } \\
\text { difference of } \\
\text { means CEO } \\
\text { and other }\end{array}$ & Mean & $\begin{array}{c}\text { T test of } \\
\text { difference of } \\
\text { means CEO } \\
\text { and other }\end{array}$ \\
\hline $\begin{array}{l}\text { Remuneration } \\
\text { board }\end{array}$ & $\begin{array}{l}\text { Yes } \\
\text { No }\end{array}$ & $\begin{array}{c}128,313 \\
89,070 \\
(-6.88 * *) \\
\end{array}$ & $\begin{array}{c}\left(14.35^{* *}\right) \\
\left(6.88^{* *}\right)\end{array}$ & $\begin{array}{c}54,083 \\
25,936 \\
(-3.51 * *)\end{array}$ & $\begin{array}{c}(-3.74 * *) \\
(-1.87 *)\end{array}$ & $\begin{array}{c}182,396 \\
115,000 \\
(-6.53 * *)\end{array}$ & $\begin{array}{l}(8.21 * *) \\
\left(5.60^{* *}\right)\end{array}$ & $\begin{array}{c}12,225 \\
9,151 \\
(-1.55)\end{array}$ & $\begin{array}{c}(-7.55 * *) \\
(4.93 * *)\end{array}$ & $\begin{array}{c}986 \\
581 \\
(-4.97 * *)\end{array}$ & $\begin{array}{l}(7.25 * *) \\
\left(4.73^{* *}\right)\end{array}$ \\
\hline Dual & $\begin{array}{l}\text { Yes } \\
\text { No }\end{array}$ & $\begin{array}{c}93,305 \\
120,350 \\
\left(4.88^{* *}\right)\end{array}$ & $\begin{array}{c}\left(5.96^{* *}\right) \\
\left(14.13^{* *}\right)\end{array}$ & $\begin{array}{c}18,824 \\
50,655 \\
(4.14 * *)\end{array}$ & $\begin{array}{l}(1.48) \\
\left(4.23^{* *}\right)\end{array}$ & $\begin{array}{l}112,129 \\
171,016 \\
(5.61 * *)\end{array}$ & $\begin{array}{c}\left(3.04^{* *}\right) \\
(10.01 * *)\end{array}$ & $\begin{array}{c}5,383 \\
12,528 \\
(4.62 * *)\end{array}$ & $\begin{array}{l}\left(5.25^{* *}\right) \\
\left(7.21^{* *}\right)\end{array}$ & $\begin{array}{c}366 \\
963 \\
(8.67 * *)\end{array}$ & $\begin{array}{l}\left(3.05^{* *}\right) \\
(8.04 * *)\end{array}$ \\
\hline $\begin{array}{l}\text { Percentage of } \\
\text { non-executives }\end{array}$ & $\begin{array}{l}\text { Below } \\
\text { median } \\
\text { Above } \\
\text { median }\end{array}$ & $\begin{array}{c}103,640 \\
127,065 \\
\left(-4.36^{* *}\right)\end{array}$ & $\begin{array}{l}\left(10.60^{* *}\right) \\
\left(11.48^{* *}\right)\end{array}$ & $\begin{array}{l}37,841 \\
\\
51,737 \\
(-1.54) \\
\end{array}$ & $\begin{array}{l}(1.72 *) \\
(4.41 * *)\end{array}$ & $\begin{array}{c}141,481 \\
178,803 \\
\left(-3.36^{* *}\right)\end{array}$ & $\begin{array}{l}\left(5.39^{* *}\right) \\
\left(8.42^{* *}\right)\end{array}$ & $\begin{array}{l}11,013 \\
\\
11,408 \\
(-0.19) \\
\end{array}$ & $\begin{array}{l}(6.81 * *) \\
\left(5.48^{* *}\right)\end{array}$ & $\begin{array}{c}804 \\
\\
901 \\
(-1.06) \\
\end{array}$ & $\begin{array}{l}(3.87 * *) \\
(7.81 * *)\end{array}$ \\
\hline Leverage & $\begin{array}{l}\text { Below } \\
\text { median } \\
\text { Above } \\
\text { median }\end{array}$ & $\begin{array}{c}117,580 \\
113,669 \\
(0.72)\end{array}$ & $\begin{array}{l}\left(10.93^{* *}\right) \\
\left(11.11^{* *}\right)\end{array}$ & $\begin{array}{c}62,055 \\
27,636 \\
(3.82 * *)\end{array}$ & $\begin{array}{l}\left(2.33^{* *}\right) \\
\left(4.37^{* *}\right)\end{array}$ & $\begin{array}{l}179,636 \\
141,305 \\
\left(3.44^{* *}\right)\end{array}$ & $\begin{array}{l}(5.61 * *) \\
((9.03 * *)\end{array}$ & $\begin{array}{c}14,480 \\
7,992 \\
\left(3.13^{* *}\right)\end{array}$ & $\begin{array}{l}\left(7.06^{* *}\right) \\
\left(5.49^{* *}\right)\end{array}$ & $\begin{array}{c}1,047 \\
662 \\
\left(4.25^{* *}\right) \\
\end{array}$ & $\begin{array}{l}(6.34 * *) \\
\left(5.90^{* *}\right)\end{array}$ \\
\hline
\end{tabular}




\section{Table 5 - Determinants of Executive Pay in the AIM Market}

This table present the results of the regressions of the different elements of pay level of the CEO and other executives. The data in Model 1 is from 2005 until 2013 and refers to 258 AIM listed companies. The data in Model 2 is from a matching sample of per value of the total number of shares granted in a specific year, valued at year end and assuming that the maximum number of shares under grant will vest; Total Pay: the sum of cash and Options and share awards. The explanatory variables are: Previous year pay element is the pound value of the previous year pay (Annual report). Leverage is the ratio of book value of debt to total assets (Datastream). Total assets is the book value of the assets in f000 (Datastream). Market to book is the ratio of the market value of equity to the book value of equity (Datastream). Previous year return is the previous year percentage change in the company share value, adjusted for dividends and capital changes (Datastream). Volatility is the annualised standard deviation of the daily share returns of one year up to the annual report year end (Datastream). Percentage of CEO ownership is the CEO share ownership and it is calculated as the number of shares held by the CEO over the total number of shares outstanding (Annual report). Board size is the number of executive and non-executive directors siting on the board (Annual report). Percentage of non-executives is the ratio of the number of non-executives to board size (Annual report). Remuneration Board is a dummy variable which takes the value of 1 if the company has a remuneration committee composed of only non-executives (Annual report). Dual is a dummy variable that takes the value of 1 if the CEO and the chair is the same individual (Annual report). The regressions include a dummy for end of year change which takes the value of 1 if the annual report date changed and for CEO change this takes the value of 1 if the CEO changed that specific year (Annual report). These two variables are not tabulated. "and " denote he coefficient is significant at the $5 \%$ and $1 \%$ level respectively. The estimated $p$ values are in parentheses.

\begin{tabular}{|c|c|c|c|c|c|c|c|c|c|c|c|c|c|c|c|c|c|c|}
\hline & \multicolumn{12}{|c|}{ Dependent Variables: Model 1- AIM } & \multicolumn{6}{|c|}{ Dependent Variables: Model 2 (GMM ONLY) } \\
\hline & \multicolumn{6}{|c|}{ Panel A- Determinants of CEO Pay level } & \multicolumn{6}{|c|}{ Panel B- Determinants of other executives pay } & \multirow{2}{*}{\multicolumn{3}{|c|}{$\begin{array}{l}\text { Panel A- Determinants of CEO } \\
\text { Pay level }\end{array}$}} & \multirow{2}{*}{\multicolumn{3}{|c|}{$\begin{array}{l}\text { Panel B- Determinants of other } \\
\text { executives pay }\end{array}$}} \\
\hline & & GMM & & & Fixed Effe & & & GMM & & & ixed Effec & & & & & & & \\
\hline & Cash & $\begin{array}{l}\text { Option } \\
+ \text { Share } \\
\text { Award }\end{array}$ & Total Pay & Cash & $\begin{array}{l}\text { Option + } \\
\text { Share } \\
\text { Award }\end{array}$ & Total Pay & Cash & $\begin{array}{l}\text { Option + } \\
\text { Share } \\
\text { Award }\end{array}$ & Total Pay & Cash & $\begin{array}{l}\text { Option } \\
\text { + Share } \\
\text { Award }\end{array}$ & $\begin{array}{l}\text { Total } \\
\text { Pay }\end{array}$ & Cash & $\begin{array}{l}\text { Option } \\
\text { + Share } \\
\text { Award }\end{array}$ & $\begin{array}{l}\text { Total } \\
\text { Pay }\end{array}$ & Cash & $\begin{array}{l}\text { Option }+ \\
\text { Share Award }\end{array}$ & $\begin{array}{l}\text { Total } \\
\text { Pay }\end{array}$ \\
\hline $\begin{array}{c}\text { Previous year } \\
\text { pay }\end{array}$ & $\begin{array}{l}0.28^{* *} \\
(0.004)\end{array}$ & $\begin{array}{c}-0.21 * * \\
(0.001)\end{array}$ & $\begin{array}{l}0.33^{* *} \\
(0.000)\end{array}$ & - & - & - & $\begin{array}{c}-0.06 \\
(0.516)\end{array}$ & $\begin{array}{c}-0.09 \\
(0.190)\end{array}$ & $\begin{array}{c}0.07 \\
(0.601)\end{array}$ & - & - & - & $\begin{array}{c}0.03 \\
(0.827)\end{array}$ & $\begin{array}{c}-0.12 \\
(0.322)\end{array}$ & $\begin{array}{c}-0.17 \\
(0.188)\end{array}$ & $\begin{array}{c}0.05 \\
(0.511)\end{array}$ & $\begin{array}{c}-0.29 \\
(0.228)\end{array}$ & $\begin{array}{c}0.10 \\
(0.063)\end{array}$ \\
\hline Total assets & $\begin{array}{l}0.29 * * \\
(0.000)\end{array}$ & $\begin{array}{l}0.95^{* *} \\
(0.000)\end{array}$ & $\begin{array}{l}0.35^{* *} \\
(0.000)\end{array}$ & $\begin{array}{c}0.31^{*} \\
(0.018)\end{array}$ & $\begin{array}{l}0.92 * * \\
(0.001)\end{array}$ & $\begin{array}{l}0.45^{* *} \\
(0.001)\end{array}$ & $\begin{array}{l}0.31 * * \\
(0.000)\end{array}$ & $\begin{array}{l}0.53^{* *} \\
(0.004)\end{array}$ & $\begin{array}{l}0.36^{* *} \\
(0.000)\end{array}$ & $\begin{array}{l}0.43^{* *} \\
(0.002)\end{array}$ & $\begin{array}{c}0.49 \\
(0.086)\end{array}$ & $\begin{array}{l}0.39^{* *} \\
(0.002)\end{array}$ & $\begin{array}{l}0.23 * * \\
(0.000)\end{array}$ & $\begin{array}{l}0.87^{* *} \\
(0.001)\end{array}$ & $\begin{array}{l}0.35^{* *} \\
(0.000)\end{array}$ & $\begin{array}{l}0.21^{* *} \\
(0.000)\end{array}$ & $\begin{array}{c}0.55^{*} \\
(0.050)\end{array}$ & $\begin{array}{l}0.23 * * \\
(0.000)\end{array}$ \\
\hline Leverage & $\begin{array}{l}-0.10^{*} \\
(0.023)\end{array}$ & $\begin{array}{c}-0.15 \\
(0.294)\end{array}$ & $\begin{array}{l}-0.12^{*} \\
(0.020)\end{array}$ & $\begin{array}{c}0.01 \\
(0.861)\end{array}$ & $\begin{array}{c}-0.07 \\
(0.675)\end{array}$ & $\begin{array}{c}-0.04 \\
(0.593)\end{array}$ & $\begin{array}{c}-0.03 \\
(0.247)\end{array}$ & $\begin{array}{l}-0.33^{*} \\
(0.017)\end{array}$ & $\begin{array}{l}-0.09 * * \\
(0.000)\end{array}$ & $\begin{array}{l}-0.07 \\
(0.183)\end{array}$ & $\begin{array}{c}-0.27 \\
(0.110)\end{array}$ & $\begin{array}{c}-0.17^{* *} \\
(0.000)\end{array}$ & $\begin{array}{c}-0.02 \\
(0.442)\end{array}$ & $\begin{array}{c}0.30 \\
(0.236)\end{array}$ & $\begin{array}{c}0.01 \\
(0.851)\end{array}$ & $\begin{array}{c}-0.48 \\
(0.060)\end{array}$ & $\begin{array}{c}1.13 \\
(0.593)\end{array}$ & $\begin{array}{c}-0.22 \\
(0.422)\end{array}$ \\
\hline Market to book & $\begin{array}{c}0.13 \\
(0.422)\end{array}$ & $\begin{array}{l}1.52^{* *} \\
(0.001)\end{array}$ & $\begin{array}{c}0.31^{*} \\
(0.047)\end{array}$ & $\begin{array}{c}-0.03 \\
(0.808)\end{array}$ & $\begin{array}{c}0.36 \\
(0.074)\end{array}$ & $\begin{array}{c}0.05 \\
(0.701)\end{array}$ & $\begin{array}{c}0.14^{*} \\
(0.014)\end{array}$ & $\begin{array}{l}0.54^{* *} \\
(0.002)\end{array}$ & $\begin{array}{l}0.23 * * \\
(0.000)\end{array}$ & $\begin{array}{c}0.10 \\
(0.242)\end{array}$ & $\begin{array}{c}0.30 \\
(0.114)\end{array}$ & $\begin{array}{c}0.21^{*} \\
(0.012)\end{array}$ & $\begin{array}{l}0.24^{* *} \\
(0.002)\end{array}$ & $\begin{array}{c}0.44 \\
(0.414)\end{array}$ & $\begin{array}{l}0.44^{* *} \\
(0.000)\end{array}$ & $\begin{array}{c}-0.16 \\
(0.061)\end{array}$ & $\begin{array}{c}0.60 \\
(0.679)\end{array}$ & $\begin{array}{c}0.06 \\
(0.663)\end{array}$ \\
\hline $\begin{array}{l}\text { Previous year } \\
\text { return }\end{array}$ & $\begin{array}{c}0.07 \\
(0.490)\end{array}$ & $\begin{array}{c}0.27 \\
(0.112)\end{array}$ & $\begin{array}{c}-0.01 \\
(0.953)\end{array}$ & $\begin{array}{c}-0.01 \\
(0.902)\end{array}$ & $\begin{array}{c}0.20 \\
(0.255)\end{array}$ & $\begin{array}{c}-0.03 \\
(0.763)\end{array}$ & $\begin{array}{l}-0.14^{*} \\
(0.032)\end{array}$ & $\begin{array}{c}0.51^{*} \\
(0.010)\end{array}$ & $\begin{array}{c}-0.07 \\
(0.158)\end{array}$ & $\begin{array}{c}-0.06 \\
(0.455)\end{array}$ & $\begin{array}{c}0.35 \\
(0.089)\end{array}$ & $\begin{array}{c}0.00 \\
(0.976)\end{array}$ & $\begin{array}{c}0.03 \\
(0.574)\end{array}$ & $\begin{array}{c}-0.69^{*} \\
(0.035)\end{array}$ & $\begin{array}{c}0.06 \\
(0.359)\end{array}$ & $\begin{array}{c}0.02 \\
(0.464)\end{array}$ & $\begin{array}{c}-0.69 \\
(0.099)\end{array}$ & $\begin{array}{c}-0.01 \\
(0.885) \\
\end{array}$ \\
\hline Volatility & $\begin{array}{c}-0.13 \\
(0.170)\end{array}$ & $\begin{array}{l}0.71^{* *} \\
(0.005)\end{array}$ & $\begin{array}{c}-0.06 \\
(0.496)\end{array}$ & $\begin{array}{c}-0.14 \\
(0.165)\end{array}$ & $\begin{array}{c}0.39 \\
(0.099)\end{array}$ & $\begin{array}{c}-0.10 \\
(0.313)\end{array}$ & $\begin{array}{c}-0.09 \\
(0.200)\end{array}$ & $\begin{array}{l}0.79 * * \\
(0.003)\end{array}$ & $\begin{array}{c}0.03 \\
(0.613)\end{array}$ & $\begin{array}{c}-0.08 \\
(0.466)\end{array}$ & $\begin{array}{c}0.27 \\
(0.276)\end{array}$ & $\begin{array}{c}-0.02 \\
(0.758)\end{array}$ & $\begin{array}{c}-0.09 \\
(0.132)\end{array}$ & $\begin{array}{c}-1.90^{* *} \\
(0.000)\end{array}$ & $\begin{array}{l}-0.18^{* *} \\
(0.000)\end{array}$ & $\begin{array}{c}-0.18 \\
(0.615)\end{array}$ & $\begin{array}{c}-0.76 \\
(0.747)\end{array}$ & $\begin{array}{c}-0.29 \\
(0.458)\end{array}$ \\
\hline $\begin{array}{c}\text { Percentage of } \\
\text { CEO ownership }\end{array}$ & $\begin{array}{c}0.00 \\
(0.925)\end{array}$ & $\begin{array}{c}0.00 \\
(0.899)\end{array}$ & $\begin{array}{c}-0.00 \\
(0.691)\end{array}$ & $\begin{array}{c}-0.00 \\
(0.499)\end{array}$ & $\begin{array}{c}0.00 \\
(0.960)\end{array}$ & $\begin{array}{c}-0.00 \\
(0.933)\end{array}$ & & & & & & & $\begin{array}{c}0.00^{*} \\
(0.030)\end{array}$ & $\begin{array}{c}-0.00^{* * *} \\
(0.000)\end{array}$ & $\begin{array}{l}-0.00^{*} \\
(0.030)\end{array}$ & & - & - \\
\hline Board Size & $\begin{array}{c}0.26 \\
(0.394)\end{array}$ & $\begin{array}{c}-0.47 \\
(0.596)\end{array}$ & $\begin{array}{c}0.04 \\
(0.898)\end{array}$ & $\begin{array}{c}0.20 \\
(0.694)\end{array}$ & $\begin{array}{c}-1.40 \\
(0.162)\end{array}$ & $\begin{array}{c}0.01 \\
(0.987)\end{array}$ & $\begin{array}{l}1.05^{* *} \\
(0.000)\end{array}$ & $\begin{array}{c}1.90^{*} \\
(0.034)\end{array}$ & $\begin{array}{l}0.87 * * \\
(0.00)\end{array}$ & $\begin{array}{c}0.89^{*} \\
(0.045)\end{array}$ & $\begin{array}{c}1.69 \\
(0.088)\end{array}$ & $\begin{array}{l}1.66^{* *} \\
(0.005)\end{array}$ & $\begin{array}{c}-0.10 \\
(0.775)\end{array}$ & $\begin{array}{c}1.63 \\
(0.287)\end{array}$ & $\begin{array}{c}0.22 \\
(0.477)\end{array}$ & $\begin{array}{c}-0.01 \\
(0.931)\end{array}$ & $\begin{array}{c}1.02 \\
(0.474)\end{array}$ & $\begin{array}{c}0.13 \\
(0.482)\end{array}$ \\
\hline $\begin{array}{c}\text { Percentage of } \\
\text { non-executives }\end{array}$ & $\begin{array}{c}-0.15 \\
(0.715)\end{array}$ & $\begin{array}{c}2.26^{*} \\
(0.039)\end{array}$ & $\begin{array}{c}0.03 \\
(0.925)\end{array}$ & $\begin{array}{c}-0.08 \\
(0.919)\end{array}$ & $\begin{array}{c}0.50 \\
(0.705)\end{array}$ & $\begin{array}{c}0.08 \\
(0.921)\end{array}$ & $\begin{array}{l}-1.60 * * \\
(0.000)\end{array}$ & $\begin{array}{c}-1.49 \\
(0.263)\end{array}$ & $\begin{array}{c}-1.40^{* * *} \\
(0.000)\end{array}$ & $\begin{array}{l}-1.59^{*} \\
(0.011)\end{array}$ & $\begin{array}{l}-3.99^{*} \\
(0.014)\end{array}$ & $\begin{array}{c}-0.24 \\
(0.154)\end{array}$ & $\begin{array}{c}-0.16 \\
(0.693)\end{array}$ & $\begin{array}{c}1.19 \\
(0.673)\end{array}$ & $\begin{array}{c}-0.11 \\
(0.811)\end{array}$ & $\begin{array}{c}0.07^{*} \\
(0.016)\end{array}$ & $\begin{array}{c}5.07 \\
(0.081)\end{array}$ & $\begin{array}{l}1.07 * * \\
(0.001)\end{array}$ \\
\hline $\begin{array}{c}\text { Remuneration } \\
\text { board }\end{array}$ & $\begin{array}{c}0.33 \\
(0.071)\end{array}$ & $\begin{array}{c}1.05^{*} \\
(0.019)\end{array}$ & $\begin{array}{c}0.31 \\
(0.064)\end{array}$ & $\begin{array}{c}-0.16 \\
(0.454)\end{array}$ & $\begin{array}{c}0.77 \\
(0.092)\end{array}$ & $\begin{array}{c}-0.09 \\
(0.658)\end{array}$ & $\begin{array}{l}0.39^{* *} \\
(0.004)\end{array}$ & $\begin{array}{c}1.06^{*} \\
(0.040)\end{array}$ & $\begin{array}{l}0.36^{* *} \\
(0.004)\end{array}$ & $\begin{array}{c}0.21 \\
(0.254)\end{array}$ & $\begin{array}{c}0.94^{*} \\
(0.048)\end{array}$ & $\begin{array}{c}-0.02 \\
(0.896)\end{array}$ & - & - & - & - & - & - \\
\hline Dual & $\begin{array}{c}-0.20 \\
(0.301)\end{array}$ & $\begin{array}{l}-1.38^{*} \\
(0.013)\end{array}$ & $\begin{array}{c}-0.13 \\
(0.485)\end{array}$ & $\begin{array}{c}-0.26 \\
(0.411)\end{array}$ & $\begin{array}{c}-0.57 \\
(0.270)\end{array}$ & $\begin{array}{c}-0.19 \\
(0.514)\end{array}$ & $\begin{array}{c}0.23 \\
(0.176)\end{array}$ & $\begin{array}{l}-1.16^{*} \\
(0.039)\end{array}$ & $\begin{array}{l}-0.31^{*} \\
(0.025)\end{array}$ & $\begin{array}{c}-0.02 \\
(0.899)\end{array}$ & $\begin{array}{c}0.16 \\
(0.758)\end{array}$ & $\begin{array}{l}6.35^{* *} \\
(0.000)\end{array}$ & $\begin{array}{c}-0.06 \\
(0.557)\end{array}$ & $\begin{array}{c}1.76 \\
(0.066)\end{array}$ & $\begin{array}{c}0.05 \\
(0.829)\end{array}$ & $\begin{array}{c}0.50 \\
(0.383)\end{array}$ & $\begin{array}{c}-33.74 * * \\
(0.000)\end{array}$ & $\begin{array}{c}-0.76 \\
(0.223)\end{array}$ \\
\hline Constant & $\begin{array}{c}5.39^{* *} \\
(0.000)\end{array}$ & $\begin{array}{c}11.80^{* *} \\
(0.000)\end{array}$ & $\begin{array}{l}4.00^{* * *} \\
(0.000)\end{array}$ & $\begin{array}{l}8.81^{* *} \\
(0.000)\end{array}$ & $\begin{array}{c}-12.17^{* * *} \\
(0.002)\end{array}$ & $\begin{array}{l}7.04 * * \\
(0.000)\end{array}$ & $\begin{array}{l}6.03 * * \\
(0.000)\end{array}$ & $\begin{array}{l}-8.90^{* * *} \\
(0.000)\end{array}$ & $\begin{array}{l}5.09^{* *} \\
(0.000)\end{array}$ & $\begin{array}{l}5.89^{* *} \\
(0.002)\end{array}$ & $\begin{array}{c}-7.13 \\
(0.066)\end{array}$ & - & $\begin{array}{c}10.53^{* *} \\
(0.000)\end{array}$ & $\begin{array}{c}0.81 \\
(0.826)\end{array}$ & $\begin{array}{c}11.54 * * \\
(0.000)\end{array}$ & $\begin{array}{c}9.45^{* * *} \\
(0.000)\end{array}$ & $\begin{array}{c}2.67 \\
(0.493)\end{array}$ & $\begin{array}{l}8.48 * * \\
(0.000)\end{array}$ \\
\hline Sargan test & $\begin{array}{c}236.1 \\
(0.003)\end{array}$ & $\begin{array}{c}230.0 \\
(0.886)\end{array}$ & $\begin{array}{c}229.9 \\
(0.887)\end{array}$ & - & - & - & $\begin{array}{c}215.5 \\
(0.972)\end{array}$ & $\begin{array}{c}220.5 \\
(0.952)\end{array}$ & $\begin{array}{c}218.8 \\
(0.960)\end{array}$ & - & - & - & $\begin{array}{l}55.6^{* *} \\
(0.008)\end{array}$ & $\begin{array}{l}58.1^{* *} \\
(0.004)\end{array}$ & $\begin{array}{l}63.2^{* *} \\
(0.001)\end{array}$ & $\begin{array}{c}38.82 \\
(0.224)\end{array}$ & $\begin{array}{c}32.86 \\
(-0.91)\end{array}$ & $\begin{array}{c}37.22 \\
(0.281)\end{array}$ \\
\hline $\mathrm{AR}(1)$ test & $\begin{array}{c}-2.9^{*} \\
(0.003)\end{array}$ & $\begin{array}{c}-4.1 * * \\
(0.000)\end{array}$ & $\begin{array}{l}-3.1^{* *} \\
(0.002)\end{array}$ & - & - & - & $\begin{array}{c}-2.9^{* *} \\
(0.004)\end{array}$ & $\begin{array}{c}-3.9^{* *} \\
(0.000)\end{array}$ & $\begin{array}{c}-2.5^{*} \\
(0.013)\end{array}$ & - & - & - & $\begin{array}{c}-1.2 \\
(0.231)\end{array}$ & $\begin{array}{c}-1.7 \\
(0.081)\end{array}$ & $\begin{array}{c}2.4^{*} \\
(0.018)\end{array}$ & $\begin{array}{c}-1.76 \\
(0.079)\end{array}$ & $\begin{array}{c}-0.91 \\
(0.363)\end{array}$ & $\begin{array}{c}-2.61 * * \\
(0.009) \\
\end{array}$ \\
\hline $\mathrm{AR}(2)$ test & $\begin{array}{c}0.8 \\
(0.396)\end{array}$ & $\begin{array}{c}-3.3^{* *} \\
(0.001)\end{array}$ & $\begin{array}{c}1.4 \\
(0.157)\end{array}$ & - & - & - & $\begin{array}{c}1.1 \\
(0.276)\end{array}$ & $\begin{array}{l}-2.8^{* *} \\
(0.005)\end{array}$ & $\begin{array}{c}0.9 \\
(0.34)\end{array}$ & - & - & - & & & & & & \\
\hline R-squared & - & - & 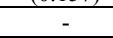 & 0.44 & 0.37 & 0.46 & - & - & - & 0.40 & 0.37 & 0.45 & & & & & & \\
\hline
\end{tabular}


Table 6 - Determinants of Executive Wealth and Risk Incentives

This table presents the results of the regressions of the wealth and risk incentives of the CEO (Panel A) and other executives (Panel B). The data in Model 1 is from 2005 until 2013 and refers to 258 AIM listed companies. The data in Model 2 is from a matching sample of firms traded in the Main Market of the London stock exchange between 2009 and 2012. All regressions include year dummies. The dependent variables are the logarithms of: Wealth incentive which is the sum of the deltas of the options and of the shares holdings, times $1 \%$ of the share price and the risk incentive which is the pound change in the portfolio of options as volatility changes by $1 \%$. The explanatory variables are: Previous year pay element is the pound value of the previous year pay. (Annual report). Leverage is the ratio of book value of debt to total assets (Datastream). Total assets is the book value of the assets in $£ 000$ (Datastream). Market to Book is the ratio of the market value of equity to the book value of equity (Datastream). Previous year return is the previous year percentage change in the company share value, adjusted for dividends and capital changes (Datastream). Volatility is the annualised standard deviation of the daily share returns of one year up to the annual report year end (Datastream). Percentage of CEO ownership is the CEO share ownership and it is calculated as the number of shares held by the CEO over the total number of shares outstanding (Annual report). Boardsize is the number of executive and nonexecutive directors siting on the board (Annual report). Percentage of non-executives is the ratio of the number of non-executives to board size (Annual report). Remuneration board is a dummy variable which takes the value of 1 if the company has a remuneration committee composed of only non-executives (Annual report). Dual is a dummy variable that takes the value of 1 if the CEO and the chair is the same individual (Annual report). The regressions include a dummy for end of year change which takes the value of 1 if the annual report date changed and for CEO change which takes the value of 1 if the CEO changed that specific year (Annual report). These two variables are not tabulated* and ** denote the coefficient is significant at the $5 \%$ and $1 \%$ level respectively. The estimated $\mathrm{p}$ values are in parentheses.

\begin{tabular}{|c|c|c|c|c|c|c|c|c|c|c|c|c|}
\hline & \multicolumn{8}{|c|}{ Dependent Variables: Model 1} & \multicolumn{4}{|c|}{ Dependent Variables: Model 2 (GMM ONLY) } \\
\hline & \multicolumn{4}{|c|}{ Panel A - CEO Wealth and risk determinants } & \multirow{2}{*}{\multicolumn{4}{|c|}{\begin{tabular}{c|c} 
Panel B - Other executives' wealth and risk determinants \\
GMM & Fixed Effects
\end{tabular}}} & \multirow{2}{*}{\multicolumn{2}{|c|}{$\begin{array}{l}\text { Panel A - CEO Wealth and risk } \\
\text { determinants }\end{array}$}} & \multirow{2}{*}{\multicolumn{2}{|c|}{$\begin{array}{l}\text { Panel B - Other executives' } \\
\text { wealth and risk determinant }\end{array}$}} \\
\hline & \multicolumn{2}{|c|}{ GMM } & \multicolumn{2}{|c|}{ Fixed Effects } & & & & & & & & \\
\hline & $\begin{array}{c}\text { Wealth } \\
\text { Incentive } \\
\text { (Delta) }\end{array}$ & $\begin{array}{c}\text { Risk } \\
\text { Incentive } \\
\text { (Vega) } \\
\end{array}$ & $\begin{array}{c}\text { Wealth } \\
\text { Incentive } \\
\text { (Delta) }\end{array}$ & $\begin{array}{c}\text { Risk } \\
\text { Incentive } \\
\text { (Vega) } \\
\end{array}$ & $\begin{array}{c}\text { Wealth } \\
\text { Incentive } \\
\text { (Delta) }\end{array}$ & $\begin{array}{c}\text { Risk } \\
\text { Incentive } \\
\text { (Vega) } \\
\end{array}$ & $\begin{array}{c}\text { Wealth } \\
\text { Incentive } \\
\text { (Delta) }\end{array}$ & $\begin{array}{c}\text { Risk } \\
\text { Incentive } \\
\text { (Vega) } \\
\end{array}$ & $\begin{array}{c}\text { Wealth } \\
\text { Incentive } \\
\text { (Delta) }\end{array}$ & $\begin{array}{c}\text { Risk } \\
\text { Incentive } \\
\text { (Vega) }\end{array}$ & $\begin{array}{c}\text { Wealth } \\
\text { Incentive } \\
\text { (Delta) }\end{array}$ & $\begin{array}{c}\text { Risk } \\
\text { Incentive } \\
\text { (Vega) } \\
\end{array}$ \\
\hline Previous year pay & $\begin{array}{c}0.21^{*} \\
(0.015)\end{array}$ & $\begin{array}{c}-0.02 \\
(0.827)\end{array}$ & - & - & $\begin{array}{c}-0.02 \\
(0.769)\end{array}$ & $\begin{array}{c}0.18^{*} \\
(0.018)\end{array}$ & - & - & $\begin{array}{c}0.07 \\
(0.347)\end{array}$ & $\begin{array}{c}0.19 \\
(0.323)\end{array}$ & $\begin{array}{c}-0.04 \\
(0.535)\end{array}$ & $\begin{array}{c}0.06 \\
(0.739)\end{array}$ \\
\hline Total assets & $\begin{array}{l}0.67 * * \\
(0.000)\end{array}$ & $\begin{array}{l}0.45^{* *} \\
(0.001)\end{array}$ & $\begin{array}{l}1.00^{* *} \\
(0.000)\end{array}$ & $\begin{array}{l}0.72 * * \\
(0.000)\end{array}$ & $\begin{array}{l}0.74 * * \\
(0.000)\end{array}$ & $\begin{array}{l}0.30^{* *} \\
(0.003)\end{array}$ & $\begin{array}{l}0.93^{* *} \\
(0.000)\end{array}$ & $\begin{array}{l}0.63 * * \\
(0.000)\end{array}$ & $\begin{array}{l}0.31^{* *} \\
(0.000)\end{array}$ & $\begin{array}{l}-0.05 \\
(0.795)\end{array}$ & $\begin{array}{c}0.27^{*} \\
(0.035)\end{array}$ & $\begin{array}{c}-0.17 \\
(0.410)\end{array}$ \\
\hline Leverage & $\begin{array}{l}-0.16^{* *} \\
(0.000)\end{array}$ & $\begin{array}{l}-0.21^{*} \\
(0.035)\end{array}$ & $\begin{array}{c}-0.19^{* *} \\
(0.000)\end{array}$ & $\begin{array}{c}-0.13 \\
(0.172)\end{array}$ & $\begin{array}{l}-0.15^{*} \\
(0.043)\end{array}$ & $\begin{array}{l}-0.15^{*} \\
(0.035)\end{array}$ & $\begin{array}{c}-0.14 \\
(0.093)\end{array}$ & $\begin{array}{l}-0.16^{*} \\
(0.042)\end{array}$ & $\begin{array}{l}-1.99 \\
(0.102)\end{array}$ & $\begin{array}{c}-1.68 \\
(0.217)\end{array}$ & $\begin{array}{c}-1.53 \\
(0.132)\end{array}$ & $\begin{array}{l}-1.67 \\
(0.353)\end{array}$ \\
\hline Market to book & $\begin{array}{l}1.62 * * \\
(0.000)\end{array}$ & $\begin{array}{l}0.47^{* *} \\
(0.001)\end{array}$ & $\begin{array}{l}1.68^{* *} \\
(0.000)\end{array}$ & $\begin{array}{c}0.35^{*} \\
(0.012)\end{array}$ & $\begin{array}{l}0.78^{* *} \\
(0.000)\end{array}$ & $\begin{array}{l}0.53^{* *} \\
(0.000)\end{array}$ & $\begin{array}{l}0.74 * * \\
(0.000)\end{array}$ & $\begin{array}{l}0.33^{* *} \\
(0.002)\end{array}$ & $\begin{array}{c}0.05 \\
(0.910)\end{array}$ & $\begin{array}{c}-3.30^{* *} \\
(0.000)\end{array}$ & $\begin{array}{c}-0.05 \\
(0.742)\end{array}$ & $\begin{array}{l}-1.38^{* *} \\
(0.009)\end{array}$ \\
\hline Previous year return & $\begin{array}{c}0.11 \\
(0.152) \\
\end{array}$ & $\begin{array}{c}0.08 \\
(0.280)\end{array}$ & $\begin{array}{c}0.15^{*} \\
(0.011)\end{array}$ & $\begin{array}{c}0.11 \\
(0.335)\end{array}$ & $\begin{array}{c}0.24^{*} \\
(0.017)\end{array}$ & $\begin{array}{c}0.08 \\
(0.358)\end{array}$ & $\begin{array}{c}0.19^{*} \\
(0.050)\end{array}$ & $\begin{array}{c}0.13 \\
(0.095)\end{array}$ & $\begin{array}{c}0.11 \\
(0.507)\end{array}$ & $\begin{array}{c}0.00 \\
(0.992) \\
\end{array}$ & $\begin{array}{c}-0.06 \\
(0.751)\end{array}$ & $\begin{array}{c}-0.34 \\
(0.183)\end{array}$ \\
\hline Volatility & $\begin{array}{c}-0.08 \\
(0.294)\end{array}$ & $\begin{array}{l}0.51^{* *} \\
(0.002)\end{array}$ & $\begin{array}{c}-0.11 \\
(0.187)\end{array}$ & $\begin{array}{c}0.04 \\
(0.865)\end{array}$ & $\begin{array}{c}0.17 \\
(0.207)\end{array}$ & $\begin{array}{c}0.30^{*} \\
(0.038)\end{array}$ & $\begin{array}{c}-0.20 \\
(0.134)\end{array}$ & $\begin{array}{c}0.07 \\
(0.686)\end{array}$ & $\begin{array}{c}-0.57 \\
(0.551)\end{array}$ & $\begin{array}{c}-1.06 \\
(0.386)\end{array}$ & $\begin{array}{c}-1.39 \\
(0.087)\end{array}$ & $\begin{array}{c}2.13 \\
(0.289)\end{array}$ \\
\hline $\begin{array}{l}\text { Percentage of CEO } \\
\text { ownership }\end{array}$ & $\begin{array}{l}3.72 * * \\
(0.007)\end{array}$ & $\begin{array}{c}0.01 * \\
(0.015)\end{array}$ & $\begin{array}{l}3.58^{* *} \\
(0.001)\end{array}$ & $\begin{array}{l}-0.00 \\
(0.505)\end{array}$ & - & - & - & - & $\begin{array}{c}0.04^{*} \\
(0.011)\end{array}$ & $\begin{array}{c}-0.00 \\
(0.658)\end{array}$ & - & - \\
\hline Board Size & $\begin{array}{c}-0.11 \\
(0.639)\end{array}$ & $\begin{array}{c}-0.11 \\
(0.848)\end{array}$ & $\begin{array}{c}-0.34 \\
(0.281)\end{array}$ & $\begin{array}{c}-0.29 \\
(0.606)\end{array}$ & $\begin{array}{l}1.55 * * \\
(0.002)\end{array}$ & $\begin{array}{c}0.45 \\
(0.287)\end{array}$ & $\begin{array}{l}1.49 * * \\
(0.002)\end{array}$ & $\begin{array}{c}0.65 \\
(0.162)\end{array}$ & $\begin{array}{c}0.66 \\
(0.378)\end{array}$ & $\begin{array}{c}-0.04 \\
(0.951)\end{array}$ & $\begin{array}{c}0.88 \\
(0.195)\end{array}$ & $\begin{array}{l}3.10^{* *} \\
(0.007)\end{array}$ \\
\hline $\begin{array}{l}\text { Percentage of non- } \\
\text { executives }\end{array}$ & $\begin{array}{c}-0.39 \\
(0.326)\end{array}$ & $\begin{array}{c}0.69 \\
(0.373)\end{array}$ & $\begin{array}{c}-0.41 \\
(0.289)\end{array}$ & $\begin{array}{c}-0.20 \\
(0.802)\end{array}$ & $\begin{array}{l}-3.51^{* *} \\
(0.000)\end{array}$ & $\begin{array}{c}-1.23 \\
(0.069)\end{array}$ & $\begin{array}{l}-3.87^{* *} \\
(0.000)\end{array}$ & $\begin{array}{l}-3.27^{* *} \\
(0.000)\end{array}$ & $\begin{array}{l}-1.54 \\
(0.219)\end{array}$ & $\begin{array}{c}-1.95 \\
(0.136)\end{array}$ & $\begin{array}{c}0.53 \\
(0.647)\end{array}$ & $\begin{array}{c}-3.23 \\
(0.128)\end{array}$ \\
\hline Remuneration board & $\begin{array}{c}0.04 \\
(0.799)\end{array}$ & $\begin{array}{c}0.62 \\
(0.098)\end{array}$ & $\begin{array}{c}-0.19 \\
(0.299)\end{array}$ & $\begin{array}{c}-0.03 \\
(0.928)\end{array}$ & $\begin{array}{c}0.40 \\
(0.096)\end{array}$ & $\begin{array}{c}0.50^{*} \\
(0.034)\end{array}$ & $\begin{array}{c}-0.09 \\
(0.695)\end{array}$ & $\begin{array}{c}0.28 \\
(0.191)\end{array}$ & - & - & - & - \\
\hline Dual & $\begin{array}{c}0.96 \\
(0.588)\end{array}$ & $\begin{array}{l}-1.13^{* *} \\
(0.004)\end{array}$ & $\begin{array}{c}0.43^{*} \\
(0.015)\end{array}$ & $\begin{array}{l}-0.61 * \\
(0.031)\end{array}$ & $\begin{array}{l}-0.88^{* *} \\
(0.006)\end{array}$ & $\begin{array}{l}-0.59^{*} \\
(0.042)\end{array}$ & $\begin{array}{l}-0.27^{*} \\
(0.324)\end{array}$ & $\begin{array}{l}-0.01 \\
(0.956)\end{array}$ & $\begin{array}{c}0.94 \\
(0.591)\end{array}$ & $\begin{array}{c}-1.02 \\
(0.141)\end{array}$ & $\begin{array}{c}2.98 \\
(0.232)\end{array}$ & $\begin{array}{c}1.64 \\
(0.368)\end{array}$ \\
\hline Constant & $\begin{array}{l}-2.44 * * \\
(0.004) \\
\end{array}$ & $\begin{array}{l}-3.93^{*} \\
(0.049)\end{array}$ & $\begin{array}{l}-3.08^{*} \\
(0.013)\end{array}$ & $\begin{array}{l}-8.26^{* * *} \\
(0.003)\end{array}$ & $\begin{array}{l}-7.13^{* *} \\
(0.000)\end{array}$ & $\begin{array}{l}-3.08^{*} \\
(0.022)\end{array}$ & $\begin{array}{c}-7.24^{* *} \\
(0.000)\end{array}$ & $\begin{array}{l}-3.55 \\
(0.099)\end{array}$ & $\begin{array}{l}5.39^{* *} \\
(0.001)\end{array}$ & $\begin{array}{c}3.75 \\
(0.171)\end{array}$ & $\begin{array}{l}4.82^{* * *} \\
(0.003)\end{array}$ & $\begin{array}{l}-0.131 \\
(0.963)\end{array}$ \\
\hline Sargan test & $\begin{array}{c}201.3 \\
{[0.403]}\end{array}$ & $\begin{array}{c}229.7 \\
{[0.889]}\end{array}$ & 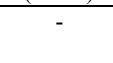 & 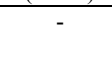 & $\begin{array}{c}219.3 \\
{[0.957]}\end{array}$ & $\begin{array}{c}204.9 \\
{[0.993]}\end{array}$ & - & 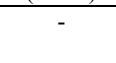 & $\begin{array}{c}21.75 \\
{[0.933]}\end{array}$ & $\begin{array}{c}45.53 \\
{[0.072]}\end{array}$ & $\begin{array}{c}28.24 \\
{[0.703]}\end{array}$ & $\begin{array}{c}33.72 \\
{[0.433]}\end{array}$ \\
\hline AR(1) test & $\begin{array}{c}-3.686^{* *} \\
{[0.000]} \\
\end{array}$ & $\begin{array}{c}-2.875^{* *} \\
{[0.004]}\end{array}$ & - & - & $\begin{array}{c}-3.988^{* *} * \\
{[0.000]}\end{array}$ & $\begin{array}{c}-4.026^{* *} \\
{[0.000]}\end{array}$ & - & - & $\begin{array}{l}-2.198^{*} \\
{[0.028]}\end{array}$ & $\begin{array}{c}0.238 \\
{[0.812]}\end{array}$ & $\begin{array}{c}-1.22 \\
{[0.224]}\end{array}$ & $\begin{array}{l}-2.04 * \\
{[0.041]}\end{array}$ \\
\hline $\mathrm{AR}(2)$ test & $\begin{array}{c}0.586 \\
{[0.558]}\end{array}$ & $\begin{array}{l}-1.415 \\
{[0.157]} \\
\end{array}$ & - & - & $\begin{array}{c}0.099 \\
{[0.912]}\end{array}$ & $\begin{array}{l}-2.421^{*} \\
{[0.015]}\end{array}$ & - & - & - & - & - & - \\
\hline R-squared & - & - & 0.76 & 0.63 & 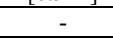 & 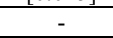 & 0.61 & 0.66 & - & - & - & - \\
\hline
\end{tabular}


Table 7 - Determinants of Executive Pay - Robustness tests

This table present the results of the regressions of the different elements of pay level of the CEO (Panel A) and other executives (Panel B). Model 3 presents the results for the Financial Distress tests and Model 4 for the Blockholder ownership tests. The data from 2005 until 2013. All regressions include year dummies. The dependent variables are the logarithms of: Cash: the sum of the annual pound values of salary, cash bonus and other benefits (Annual report); Options and share awards: the sum of the pound value of the total number of options granted in a specific year, valued at year end using the Black and Scholes model adjusted for dividend payment and the pound value of the total number of shares granted in a specific year, valued at year end and assuming that the maximum number of shares under grant will vest; Total Pay: the sum of cash and Options and share awards. The explanatory variables are: Previous year pay element is the pound value of the previous year pay. (Annual report). Leverage is the ratio of book value of debt to total assets (Datastream). Total assets is the book value of the assets in $£ 000$ (Datastream). Market to book is the ratio of the market value of equity to the book value of equity (Datastream). Previous year return is the previous year percentage change in the company share value, adjusted for dividends and capital changes (Datastream). Volatility is the annualised standard deviation of the daily share returns of one year up to the annual report year end (Datastream). Boardsize is the number of executive and non-executive directors siting on the board (Annual report). Percentage of non-executives is the ratio of the number of non-executives to board size (Annual report). Remuneration Board is a dummy variable which takes the value of 1 if the company has a remuneration committee composed of only non-executives (Annual report). Dual is a dummy variable that takes the value of 1 if the CEO and the chair is the same individual (Annual report). Model 3 includes the following additional variables: Distress is a dummy variable if the firm's $Z$ score is below 1.8 . Leverage*Distress is the product of Distress and Leverage. Model 4 includes the capita share ownership of the other excutive directors is $3 \%$ or more (Annul report). Blockholder Ownership is the total percentage share ownership held by Blockholders. Low experience is a dumy variable which takes the val 1 . 1 if te CEO experience is on the lower quartile of the distribution. High experience is a dummy varible which thes the value of 1 if the CEO experience is on the upper quartile of the experience distribution All regressions include a dummy for end of yea

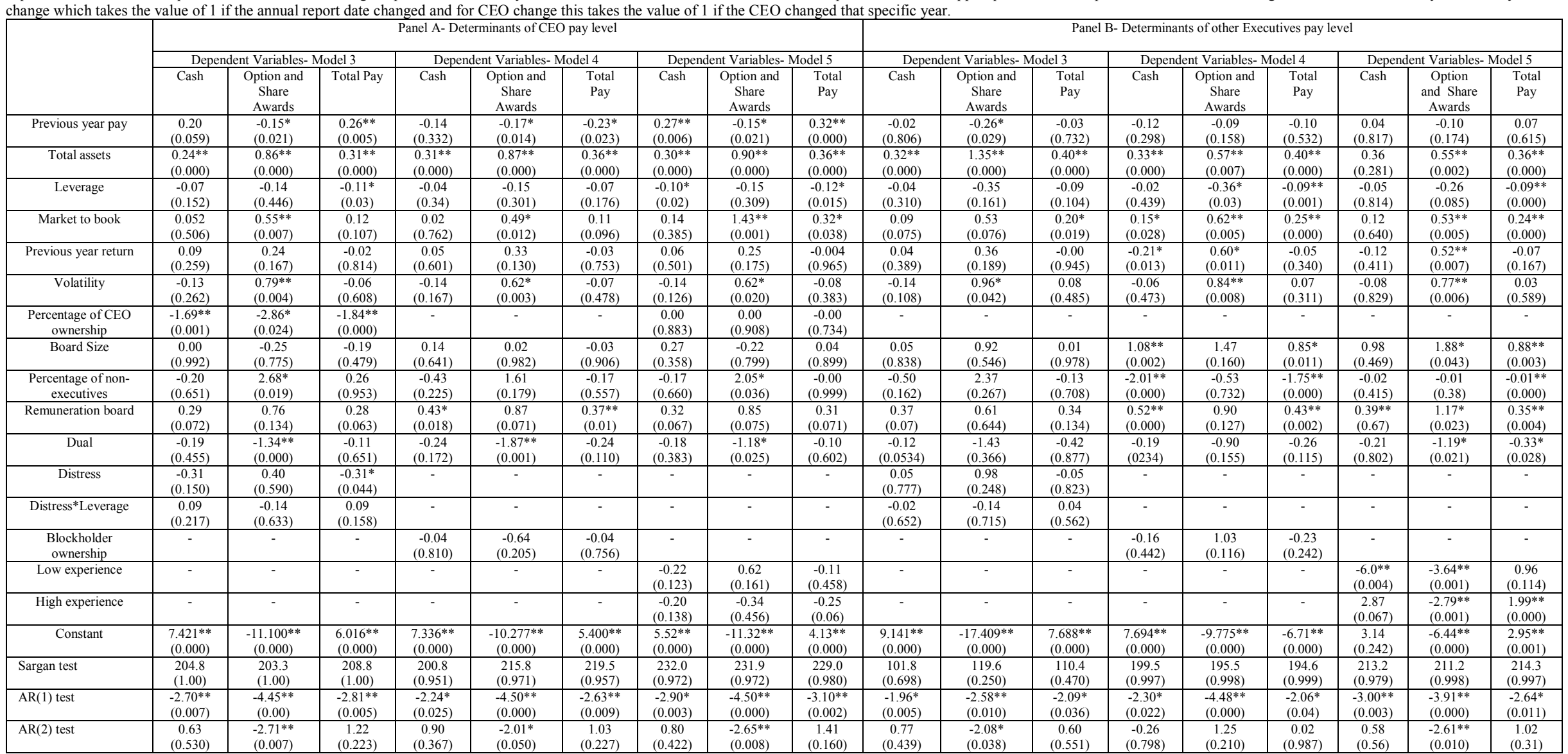




\section{Table 8 - Determinants of Executive Wealth and Risk Incentives- Robustness tests}

This table presents the results of the regressions of the wealth and risk incentives of the CEO (Panel A) and other executives (Panel B) for the firms in our sample. Model 3 presents the results for the Financial Distress tests and Model 4 for the Blockholder ownership tests. The data from 2005 until 2013.All regressions include year dummies. The dependent variables are the logarithms of: Wealth incentive which is the sum of the deltas of the options and of the shares holdings, times $1 \%$ of the share price and the risk incentive which is the pound change in the portfolio of options as volatility changes by $1 \%$. The explanatory variables are. Previous year pay element is the pound value of the previous year pay. (Annual report). Leverage is the ratio of book value of debt to total assets (Datastream). Total assets is the book value of the assets in 1000 (Datastream). Market to Book is the ratio of the market value of equity to the book value of equity (Datastream). Previous year return is the previous year percentage change in the company share value, adjusted for dividends and capital changes (Datastream). Volatility is the annualised standard deviation of the daily share returns of one year up to the annual report year end (Datastream). Percentage of CEO ownership is the CEO share ownership and it is calculated as the number of shares held by the CEO over the total number of shares outstanding (Annual report). Boardsize is the number of executive and non- executive directors siting on the board (Annual report). Percentage of non-executives is the ratio of the number of non-executives to board size (Annual report). Remuneration board is a dummy variable which takes the value of 1 if the company has Distress is a CEO owns $3 \%$ or more of the comany shes (Anul report). Blockholder director is a dummy varible which takes the value of 1 if the per capita share ownership of the other executive directors is $3 \%$ or more (Annul report). Blockholder Ownership is the total percentage share ownership held by Blockholders. Low experience is a dummy variable which takes the value of 1 if the CEO experience is on the lower quartile of the distribution. High experience is a dummy variable which takes the value of 1 if the $\mathrm{CEO}$ experience is on the upper quartile of the experience distribution. All regressions include a dummy for end of year change which takes the value of 1 if the annual report date changed and for CEO change this takes the value of 1 if the CEO changed that specific year (Annual report). These two variables are not tabulated. * and ** denote the coefficient is significant at the $5 \%$ and $1 \%$ level respectively. The estimated $\mathrm{p}$ values are in parentheses.

\begin{tabular}{|c|c|c|c|c|c|c|c|c|c|c|c|c|}
\hline \multirow{3}{*}{ 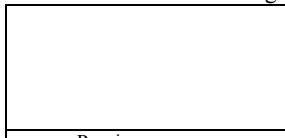 } & \multirow{2}{*}{\multicolumn{6}{|c|}{ Panel A-Determinants of CEO pay level }} & \multirow{2}{*}{\multicolumn{6}{|c|}{$\begin{array}{c}\text { Panel B- Determinants of other Executives pay level } \\
\end{array}$}} \\
\hline & \multicolumn{2}{|c|}{ Dependent Variables-Model 3} & \multicolumn{2}{|c|}{ Dependent Variables-Model 4} & Dependent Variables-Model 5 & & & & & & & Dependent Variables-Model 5 \\
\hline & $\begin{array}{l}\text { Wealth } \\
\text { Incentive } \\
\text { (Delta) }\end{array}$ & $\begin{array}{l}\text { Risk Incentive } \\
\text { (Vega) }\end{array}$ & $\begin{array}{l}\text { Wealth } \\
\text { Incentive } \\
\text { (Delta) }\end{array}$ & $\begin{array}{l}\text { Risk Incentive } \\
\text { (Vega) }\end{array}$ & $\begin{array}{l}\text { Wealth Incentive } \\
\text { (Delta) }\end{array}$ & $\begin{array}{c}\text { Risk Incentive } \\
\text { (Vega) }\end{array}$ & $\begin{array}{c}\text { Wealth } \\
\text { Incentive } \\
\text { (Delta) }\end{array}$ & $\begin{array}{c}\text { Risk Incentive } \\
\text { (Vega) }\end{array}$ & $\begin{array}{l}\text { Wealth } \\
\text { Incentive } \\
\text { (Delta) }\end{array}$ & $\begin{array}{c}\text { Risk Incentive } \\
\text { (Vega) }\end{array}$ & $\begin{array}{c}\text { Wealth } \\
\text { Incentive } \\
\text { (Delta) }\end{array}$ & $\begin{array}{l}\text { Risk Incentive } \\
\text { (Vega) }\end{array}$ \\
\hline Previous year pay & $\begin{array}{l}0.24 * * \\
(0.000)\end{array}$ & $\begin{array}{c}0.06 \\
(0.452)\end{array}$ & $\begin{array}{c}0.18 \\
(0.107)\end{array}$ & $\begin{array}{c}-0.05 \\
(0.610)\end{array}$ & $\begin{array}{l}0.38^{* *} \\
(0.000)\end{array}$ & $\begin{array}{c}0.12 \\
(0.168)\end{array}$ & $\begin{array}{l}-0.05 \\
(0.605)\end{array}$ & $\begin{array}{l}0.19 * \\
(0.040)\end{array}$ & $\begin{array}{c}-0.02 \\
(0.822)\end{array}$ & $\begin{array}{l}0.16^{*} \\
(0.05)\end{array}$ & $\begin{array}{c}0.07 \\
(0.389)\end{array}$ & $\begin{array}{l}0.26 * * \\
(0.001)\end{array}$ \\
\hline Total assets & $0.68^{* * *}$ & $0.34^{*}$ & $0.62 * *$ & $0.48^{* * *}$ & $0.55^{* *}$ & $0.42^{* *}$ & $\begin{array}{l}0.60 * * \\
0.000\end{array}$ & $0.46^{* *}$ & $\begin{array}{l}0.73^{* *} \\
0.000\end{array}$ & $0.37^{* *}$ & $0.71 * *$ & $0.31 * *$ \\
\hline Leverage & $\frac{(0.000)}{-0.15^{* *}}$ & $\frac{(0.021)}{-0.17}$ & $-0.11^{* *}$ & $\frac{0.000}{-0.16^{* *}}$ & $-0.16^{*}$ & $\frac{0.001}{-0.22^{*}}$ & $-0.21^{*}$ & 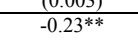 & -0.09 & -0.13 & $\frac{0.000}{-0.14^{*}}$ & $-0.16^{*}$ \\
\hline & $(0.001)$ & $(0.174)$ & $(0.001)$ & $(0.096)$ & $(0.012)$ & $(0.016)$ & $(0.024)$ & $(0.05)$ & $(0.248)$ & $(0.111)$ & $(0.041)$ & $(0.012)$ \\
\hline Market to book & $\begin{array}{l}0.70^{* *} \\
(0.000)\end{array}$ & $\begin{array}{l}0.43^{* *} \\
0.003\end{array}$ & $\begin{array}{l}0.65^{* *} \\
0.000\end{array}$ & $\begin{array}{l}0.47 * * \\
0.000)\end{array}$ & 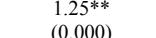 & $\begin{array}{l}0.94 * * \\
(0.000)\end{array}$ & $\begin{array}{l}0.70^{* *} \\
(0.000)\end{array}$ & $\left.\begin{array}{l}0.39^{* *} \\
0.005\end{array}\right)$ & $\begin{array}{l}0.83^{* *} \\
0.000)\end{array}$ & $\begin{array}{l}0.59^{* *} \\
(0.000)\end{array}$ & $\begin{array}{l}0.81 * * \\
(0.000)\end{array}$ & $\begin{array}{l}0.51^{* *} \\
0.000)\end{array}$ \\
\hline Previous year return & $\begin{array}{l}0.004 \\
0.601)\end{array}$ & $\begin{array}{l}0.00 \\
0.983)\end{array}$ & $\begin{array}{l}0.12 \\
(0.282)\end{array}$ & 0.01 & $\begin{array}{l}0.22^{*} \\
0.011\end{array}$ & 0.03 & $\begin{array}{l}0.099 \\
0.296)\end{array}$ & $\begin{array}{l}-0.06 \\
-0.621)\end{array}$ & $\begin{array}{c}0.27^{*} \\
(0.020)\end{array}$ & $\begin{array}{c}0.02 \\
(0.809)\end{array}$ & $\begin{array}{c}0.174 \\
(0.108)\end{array}$ & 0.09 \\
\hline Volatility & $\begin{array}{l}(0.601) \\
-0.07 \\
0.432\end{array}$ & $\begin{array}{c}(0.983) \\
0.58^{* *}\end{array}$ & $\begin{array}{l}(0.282) \\
-0.17 \\
(0.09)\end{array}$ & $\begin{array}{l}0.945) \\
0.49^{*}\end{array}$ & $\begin{array}{l}\frac{(0.011)}{-0.16} \\
0.899\end{array}$ & $\begin{array}{l}\frac{(0.121)}{0.37^{*}} \\
0.016\end{array}$ & $\begin{array}{l}-0.12 \\
0.382\end{array}$ & $\begin{array}{l}(0.621) \\
0.66^{1 * *} \\
0.004)\end{array}$ & 0.17 & $0.37^{*}$ & $\begin{array}{l}(0.108) \\
0.11 \\
0431\end{array}$ & $\begin{array}{c}(0.311) \\
0.29 \\
(0.073)\end{array}$ \\
\hline Percentage of CEO ownership & $\frac{(0.432)}{3.62^{* *}}$ & $\frac{(0.003)}{-2.60^{* *}}$ & $\begin{array}{c}(0.09) \\
-\end{array}$ & $\frac{(0.012)}{-}$ & $\frac{(0.899)}{0.02^{2 *}}$ & $\frac{(0.016)}{0.00}$ & $\frac{(0.382)}{-}$ & $\frac{(0.004)}{-}$ & $\frac{(0.326)}{-}$ & $\frac{(0.05)}{-}$ & $\frac{(0.431)}{-}$ & $\frac{(0.073)}{-}$ \\
\hline Board Size & $\frac{(0.001)}{-0.05}$ & $\begin{array}{c}(0.016) \\
-0.29\end{array}$ & -0.21 & -0.44 & $\frac{(0.000)}{0.24}$ & $\frac{(0.093)}{0.05}$ & -0.13 & -0.26 & $1.01^{*}$ & 0.24 & $1.41^{* *}$ & 0.396 \\
\hline & $(0.836)$ & $(0.591)$ & $(0.506)$ & $(0.514)$ & $(0.528)$ & $(0.921)$ & $(0.861)$ & $(0.682)$ & $(0.021)$ & $(0.641)$ & $(0.005)$ & $(0.381)$ \\
\hline Percentage of non-executives & $\begin{array}{l}-0.41 \\
(0.311)\end{array}$ & $\begin{array}{l}1.35 \\
(0.081)\end{array}$ & $\begin{array}{l}-0.86 \\
(0.078)\end{array}$ & $\begin{array}{l}1.58 \\
(0.121)\end{array}$ & $\begin{array}{l}-0.29 \\
(0.609)\end{array}$ & $\begin{array}{c}0.47 \\
(0.494)\end{array}$ & $\begin{array}{l}-1.07 \\
(0.230)\end{array}$ & $\begin{array}{l}2.12^{*} \\
(0.037)\end{array}$ & $\begin{array}{l}-3.38^{* *} \\
(0.000)\end{array}$ & $\begin{array}{l}-1.08 \\
(0.157)\end{array}$ & $\begin{array}{l}-0.03 * * \\
(0.000)\end{array}$ & $\begin{array}{l}-0.01^{*} \\
(0.046)\end{array}$ \\
\hline Remuneration board & $\begin{array}{l}-0.02 \\
(0.920)\end{array}$ & $\begin{array}{l}0.45 \\
(0.175) \\
\end{array}$ & $\begin{array}{l}-0.10 \\
(0.654) \\
\end{array}$ & $\begin{array}{l}-0.06 \\
(0.835) \\
\end{array}$ & $\begin{array}{l}-0.04 \\
(0.839) \\
\end{array}$ & $\begin{array}{c}0.54 \\
(0.062) \\
\end{array}$ & $\begin{array}{l}-0.58 \\
(0.309) \\
\end{array}$ & $\begin{array}{c}0.35 \\
(0.524) \\
\end{array}$ & $\begin{array}{l}-0.42 \\
(0.136)\end{array}$ & $\begin{array}{l}0.45 \\
(0.100)\end{array}$ & $\begin{array}{l}0.37 \\
(0.119) \\
\end{array}$ & $\begin{array}{l}0.48^{*} \\
(0.05)\end{array}$ \\
\hline Dual & $\begin{array}{l}0.14 \\
(0.391) \\
\end{array}$ & $\begin{array}{l}-0.95^{*} \\
(0.023)\end{array}$ & $\begin{array}{c}0.56^{*} \\
(0.013) \\
\end{array}$ & $\begin{array}{l}-1.32 * * \\
(0.000) \\
\end{array}$ & $\begin{array}{c}0.01 \\
(0.986)\end{array}$ & $\begin{array}{c}-0.66 \\
(0.070)\end{array}$ & $\begin{array}{c}-0.15 \\
(0.772) \\
\end{array}$ & $\begin{array}{l}-0.59 \\
(0.349) \\
\end{array}$ & $\begin{array}{l}-0.68^{*} \\
(0.038)\end{array}$ & $\begin{array}{c}-0.33 \\
(0.323) \\
\end{array}$ & $\begin{array}{l}-0.87 * * \\
(0.003) \\
\end{array}$ & $\begin{array}{l}-0.61^{*} \\
(0.03)\end{array}$ \\
\hline Distress & $\begin{array}{c}-0.45^{*} \\
(0.021)\end{array}$ & $\begin{array}{c}-0.59 \\
(0.159) \\
\end{array}$ & - & - & - & - & $\begin{array}{c}-0.65^{*} \\
(0.038)\end{array}$ & $\begin{array}{r}-0.19 \\
0.637 \\
\end{array}$ & - & - & - & - \\
\hline $\begin{array}{l}\text { Distress*Leverage } \\
\end{array}$ & $\begin{array}{l}-0.06 \\
(0.454) \\
\end{array}$ & $\begin{array}{c}0.15 \\
(0.362) \\
\end{array}$ & - & - & - & - & $\begin{array}{c}0.04 \\
(0.761) \\
\end{array}$ & $\begin{array}{c}0.11 \\
(0.537) \\
\end{array}$ & - & - & - & - \\
\hline Blockholder ownership & - & - & $\begin{array}{c}0.08 \\
(0.672)\end{array}$ & $\begin{array}{c}-0.37 \\
(0.174) \\
(0.17\end{array}$ & - & - & - & - & $\begin{array}{c}-0.35 \\
(0.259) \\
\end{array}$ & $\begin{array}{c}0.04 \\
(0.899) \\
\end{array}$ & - & - \\
\hline Low experience & - & - & - & & $\begin{array}{r}-0.48^{*} \\
(0.016) \\
\end{array}$ & $\begin{array}{c}0.24 \\
(0.377) \\
\end{array}$ & - & - & - & - & $\begin{array}{l}-3.11 * * \\
(0.000) \\
\end{array}$ & $\begin{array}{l}-1.57 * * \\
(0.004) \\
\end{array}$ \\
\hline High experience & - & - & - & - & $\begin{array}{c}0.12 \\
(0.499)\end{array}$ & $\begin{array}{l}-0.91 * * \\
(0.004)\end{array}$ & - & - & - & - & $\begin{array}{l}-2.13 * * \\
(0.000)\end{array}$ & $\begin{array}{c}-0.87 \\
(0.08)\end{array}$ \\
\hline Constant & $\begin{array}{l}-2.91 * * \\
(0.001)\end{array}$ & $\begin{array}{c}-2.79 \\
(0.167) \\
\end{array}$ & $\begin{array}{c}-0.23 \\
(0.86) \\
\end{array}$ & $\begin{array}{l}-4.22^{*} \\
(0.032) \\
\end{array}$ & $\begin{array}{l}-2.40^{*} \\
(0.050) \\
\end{array}$ & $\begin{array}{c}-3.41 \\
(0.076) \\
\end{array}$ & $\begin{array}{c}1.55 \\
(0.367) \\
\end{array}$ & $\begin{array}{l}-4.93^{*} \\
(0.03) \\
\end{array}$ & $\begin{array}{l}-6.15^{* *} \\
(0.000)\end{array}$ & $\begin{array}{r}-3.76 \\
(0.03) \\
\end{array}$ & $\begin{array}{l}-5.25 * * \\
(0.000) \\
\end{array}$ & $\begin{array}{r}-2.44 \\
(0.008) \\
\end{array}$ \\
\hline Sargan test & $\begin{array}{c}198.3 \\
(0.974)\end{array}$ & $\begin{array}{l}206.3 \\
(1.00)\end{array}$ & $\begin{array}{c}193.3 \\
(0.562)\end{array}$ & $\begin{array}{l}214.9 \\
(0.974)\end{array}$ & $\begin{array}{l}232.5 \\
(0.970)\end{array}$ & $\begin{array}{l}220.5 \\
(0.993)\end{array}$ & $\begin{array}{c}110.3 \\
(0.479)\end{array}$ & $\begin{array}{c}119.4 \\
(0.255)\end{array}$ & $\begin{array}{l}184.8 \\
(1.00)\end{array}$ & $\begin{array}{c}194.7 \\
(0.999)\end{array}$ & $\begin{array}{l}216.2 \\
(0.996)\end{array}$ & $\begin{array}{c}205.2 \\
(0.999)\end{array}$ \\
\hline $\mathrm{AR}(1)$ test & $\begin{array}{l}-3.39 * * \\
(0.001)\end{array}$ & $\begin{array}{l}-3.58^{* * *} \\
(0.000)\end{array}$ & $\begin{array}{l}-3.44^{* *} \\
(0.001)\end{array}$ & $\begin{array}{l}-3.14 * * \\
(0.002)\end{array}$ & $\begin{array}{l}-4.84 * * \\
(0.000)\end{array}$ & $\begin{array}{l}-3.86^{* * *} \\
(0.000)\end{array}$ & $\begin{array}{l}-2.45^{*} \\
(0.014)\end{array}$ & $\begin{array}{c}3.08^{*} \\
(0.002)\end{array}$ & $\begin{array}{c}-3.52^{* *} \\
(0.000)\end{array}$ & $\begin{array}{l}-3.48 * * \\
(0.000)\end{array}$ & $\begin{array}{l}-3.93^{* *} \\
(0.000)\end{array}$ & $\begin{array}{l}-4.30 * * \\
(0.000)\end{array}$ \\
\hline $\mathrm{AR}(2)$ test & $\begin{array}{c}-0.65 \\
(0.516) \\
\end{array}$ & $\begin{array}{l}-1.04 \\
(0.298)\end{array}$ & $\begin{array}{c}0.70 \\
(0.483) \\
\end{array}$ & $\begin{array}{l}0.002) \\
-0.99 \\
(0.32) \\
\end{array}$ & $\begin{array}{c}1.09 \\
(0.273) \\
\end{array}$ & $\begin{array}{c}0.0078 \\
(0.435) \\
\end{array}$ & $\begin{array}{c}-1.23 \\
(0.198) \\
\end{array}$ & $\begin{array}{c}0.002) \\
(0.486) \\
(0.626)\end{array}$ & $\begin{array}{c}-0.02 \\
(0.987)\end{array}$ & $\begin{array}{l}-1.50 \\
(0.133) \\
\end{array}$ & $\begin{array}{c}0.51 \\
(0.602)\end{array}$ & $\begin{array}{l}-1.88 \\
(0.06) \\
\end{array}$ \\
\hline
\end{tabular}


Appendix A

\begin{tabular}{|c|c|}
\hline \multicolumn{2}{|c|}{ Summary of QCA code of good corporate governance practice } \\
\hline 1. The board & \\
\hline Role of Chairman & $\begin{array}{l}\text { The role of Chairman and CEO should be } \\
\text { separated. }\end{array}$ \\
\hline Independent non-executive directors & $\begin{array}{l}\text { The board should have at least } 2 \text { non- } \\
\text { executive independent directors. }\end{array}$ \\
\hline $\begin{array}{l}\text { 2. Independence of non-executive } \\
\text { directors }\end{array}$ & $\begin{array}{l}\text { The criteria for assessing the independence } \\
\text { of non-executive directors set out in the } \\
\text { UK Corporate Governance Code is useful } \\
\text { for adoption by AIM companies }\end{array}$ \\
\hline 3. Re-election & $\begin{array}{l}\text { All directors should be submitted for re- } \\
\text { election at regular intervals. }\end{array}$ \\
\hline 4. Audit Committee & $\begin{array}{l}\text { There should be a separate committee with } \\
\text { at least } 2 \text { independent non-executive } \\
\text { directors. }\end{array}$ \\
\hline 5. Remuneration Committee & $\begin{array}{l}\text { There should be a separate committee with } \\
\text { at least } 2 \text { members all of which should be } \\
\text { independent non-executive directors. }\end{array}$ \\
\hline 6. Nomination Committee & $\begin{array}{l}\text { Recommendations for board nomination } \\
\text { should be made by a nominations' } \\
\text { committee. }\end{array}$ \\
\hline 7. Dialogue with shareholders & $\begin{array}{l}\text { The board has the responsibility to ensure } \\
\text { the dialogue with shareholders. }\end{array}$ \\
\hline 8. Matters reserved to the board & $\begin{array}{l}\text { There should be a formal schedule of } \\
\text { matters reserved for the board decision. }\end{array}$ \\
\hline 9. Timely Information & $\begin{array}{l}\text { The board should be timely supplied with } \\
\text { information. }\end{array}$ \\
\hline 10. Internal Controls review & $\begin{array}{l}\text { At a minimum the board should annually } \\
\text { review the company's internal processes } \\
\text { and report the outcome to shareholders. }\end{array}$ \\
\hline
\end{tabular}


Appendix B - Research on determinants of executive pay and incentives in the UK Main Market

\begin{tabular}{|c|c|c|c|c|c|c|c|c|}
\hline \multirow[b]{2}{*}{ Paper } & \multirow[b]{2}{*}{ Sample } & \multirow[b]{2}{*}{ Dependent variable } & \multicolumn{6}{|c|}{ Independent Variables } \\
\hline & & & $\begin{array}{l}\text { Debt holders } \\
\text { (significance) }\end{array}$ & $\begin{array}{l}\text { Outside ownership } \\
\text { (significance) }\end{array}$ & $\begin{array}{c}\text { Remuneration Committee } \\
\text { (significance) }\end{array}$ & $\begin{array}{c}\text { Board Size } \\
\text { (significance) }\end{array}$ & Board independence (significance) & $\begin{array}{c}\text { Dual Roles } \\
\text { (significance) }\end{array}$ \\
\hline $\begin{array}{l}\text { Main and Johnston } \\
\text { (1993) }\end{array}$ & $\begin{array}{l}220 \text { Large UK } \\
\text { firms (1990) }\end{array}$ & $\begin{array}{l}\text { Log of pay of highest paid } \\
\text { director and pay structure } \\
\text { (options over total pay) }\end{array}$ & Not Tested & Not Tested & $\begin{array}{c}\text { Dummy for existence } \\
\text { (positive for total pay) } \\
\text { (not significant for structure) }\end{array}$ & Not Tested & $\begin{array}{c}\% \text { non-executives } \\
\text { (positive for total pay) } \\
\text { (not significant for structure) }\end{array}$ & $\begin{array}{c}\text { Dummy (yes } / \mathrm{no}) \\
\text { (not significant }\end{array}$ \\
\hline $\begin{array}{l}\text { Conyon and Leech } \\
\text { (1994) }\end{array}$ & $\begin{array}{l}\text { 294 Large UK } \\
\text { firms (1985) }\end{array}$ & $\begin{array}{l}\text { Change in log cash of highest } \\
\text { director }\end{array}$ & Not Tested & $\begin{array}{l}\text { Ownership concentration (sum } \\
\text { of largest five ownership) } \\
\text { (not significant) }\end{array}$ & Not Tested & Not Tested & Not Tested & $\begin{array}{l}\text { Dummy (yes/no) } \\
\text { (Not significant) }\end{array}$ \\
\hline Conyon (1997) & $\begin{array}{c}213 \text { Large UK } \\
(1988-1993)\end{array}$ & $\begin{array}{l}\text { Change in log of cash of } \\
\text { highest paid director }\end{array}$ & Not Tested & Not Tested & $\begin{array}{c}\text { Dummy for existence } \\
\text { (negative and significant) }\end{array}$ & Not Tested & Not Tested & $\begin{array}{l}\text { Dummy (yes/no) } \\
\text { (not significant) }\end{array}$ \\
\hline $\begin{array}{l}\text { Cosh and Hughes } \\
\text { (1997) }\end{array}$ & $\begin{array}{l}\text { 64 UK Electrical } \\
\text { Engineering firms }\end{array}$ & Level and change in CEO pay & Not Tested & $\begin{array}{l}\text { Dummy identifying strong } \\
\text { institutional presence } \\
\text { (not significant) }\end{array}$ & Not Tested & Not Tested & $\begin{array}{c}\% \text { non-executives } \\
\text { (significant and positive) }\end{array}$ & Not Tested \\
\hline $\begin{array}{l}\text { Conyon and Peck } \\
\text { (1998) }\end{array}$ & $\begin{array}{c}94 \text { large FTSE } \\
100 \text { firms (1991- } \\
1994)\end{array}$ & $\begin{array}{l}\text { Level of cash of highest paid } \\
\text { director }\end{array}$ & Not Tested & $\begin{array}{c}\% \text { of shares held by the largest } \\
\text { shareholder } \\
\text { (not significant) }\end{array}$ & $\begin{array}{l}\text { Dummy for existence and percentage } \\
\text { of non-executives } \\
\text { (dummy not significant) } \\
\text { (proportion negative and significant) }\end{array}$ & Not Tested & $\begin{array}{l}\text { \% non-executives } \\
\text { (not significant) }\end{array}$ & $\begin{array}{l}\text { Dummy (yes/no) } \\
\text { (not significant) }\end{array}$ \\
\hline $\begin{array}{l}\text { Benito and Conyon } \\
\text { (1999) }\end{array}$ & $\begin{array}{l}211 \text { UK (1985- } \\
\text { 1994) }\end{array}$ & $\begin{array}{l}\text { Log of cash of highest paid } \\
\text { director }\end{array}$ & Not Tested & Not Tested & $\begin{array}{l}\text { Dummy for existence } \\
\text { (not significant) }\end{array}$ & Not Tested & Not Tested & $\begin{array}{l}\text { Dummy (yes/no) } \\
\text { (not significant) }\end{array}$ \\
\hline Ozkan (2007) & $\begin{array}{l}114 \text { UK (2003- } \\
2004)\end{array}$ & CEO total compensation & Not Tested & $\begin{array}{l}\text { \% total Blockholder } \\
\text { (significant and negative) } \\
\% \text { total institutional } \\
\text { (significant and negative) }\end{array}$ & Not Tested & $\begin{array}{l}\text { Count (number of } \\
\text { directors on the } \\
\text { board) } \\
\text { (significant and } \\
\text { positive) }\end{array}$ & $\begin{array}{c}\% \text { non-executives } \\
\text { (significant and positive) }\end{array}$ & Not Tested \\
\hline $\begin{array}{l}\text { Voulgaris et al. } \\
\text { (2010) }\end{array}$ & $\begin{array}{l}500 \text { UK Main } \\
\text { Market companies } \\
(2006)\end{array}$ & $\begin{array}{l}\text { a. Log of CEO total pay } \\
\text { b. Log of CEO equity pay }\end{array}$ & $\begin{array}{l}\text { Leverage is taken } \\
\text { from Datastream } \\
\text { ratio } \\
\text { a. (not significant) } \\
\text { b. (not significant) }\end{array}$ & $\begin{array}{l}\text { a. }(\text { not significant }) \\
\text { b. (not significant) }\end{array}$ & $\begin{array}{l}\text { a. (significant and positive) } \\
\text { b. (not significant) }\end{array}$ & Not Tested & $\begin{array}{c}\text { a. (not significant) } \\
\text { b. (significant and positive) }\end{array}$ & Not Tested \\
\hline Gregg et al. (2012) & $\begin{array}{l}\text { 415 Large UK } \\
(1994-2006)\end{array}$ & $\begin{array}{c}\text { Log (cash total board pay) } \\
\log \text { (cash highest pay director) }\end{array}$ & Not Tested & Not Tested & Not Tested & $\begin{array}{l}\text { Count (number of } \\
\text { directors on the } \\
\text { board) } \\
\text { (not significant) }\end{array}$ & $\begin{array}{c}\% \text { non-executives } \\
\text { (significant and positive) }\end{array}$ & Not Tested \\
\hline $\begin{array}{l}\text { Gregory-Smith } \\
\text { (2012) }\end{array}$ & $\begin{array}{l}\text { UK FTSE 350 } \\
(1996-2008)\end{array}$ & $\begin{array}{l}\text { Log of CEO pay (total pay - } \\
\text { grants are estimated at face } \\
\text { value) }\end{array}$ & Not Tested & $\begin{array}{c}\text { \% of ownership } \\
\text { (significant and negative) }\end{array}$ & $\begin{array}{l}\% \text { of insiders on board } \\
\text { (not significant) }\end{array}$ & $\begin{array}{l}\text { Count (number of } \\
\text { directors on the } \\
\text { board) } \\
\text { (not significant) }\end{array}$ & $\begin{array}{c}\% \text { insider } \\
\text { (not significant) } \\
\text { Number of non-executives } \\
\text { (significant and positive) }\end{array}$ & $\begin{array}{l}\text { Dummy (yes/no) } \\
\text { (not significant) }\end{array}$ \\
\hline $\begin{array}{l}\text { Fernandes et al. } \\
\text { (2013) }\end{array}$ & $\begin{array}{l}3012 \text { large US and } \\
\text { non-US firms } \\
(2006)\end{array}$ & Log of CEO total pay & $\begin{array}{l}\text { Leverage as Total } \\
\text { debt divided by } \\
\text { total assets } \\
\text { (significant and } \\
\text { positive) } \\
\end{array}$ & $\begin{array}{l}\text { share ownership of all } \\
\text { institutional owners } \\
\text { (significant and positive) }\end{array}$ & Not Tested & $\begin{array}{l}\text { Count (number of } \\
\text { directors on the } \\
\text { board) } \\
\text { (not significant) }\end{array}$ & $\begin{array}{l}\% \text { of independent directors (directors } \\
\text { whom are not employed by the firm or } \\
\text { affiliated with the firm) } \\
\text { (significant and positive) }\end{array}$ & $\begin{array}{l}\text { Dummy (yes/no) } \\
\text { (not significant) }\end{array}$ \\
\hline
\end{tabular}

Total pay cash and equity pay 